\title{
Neuronal Phenotype in the Mature Nervous System Is Maintained by Persistent Retrograde Bone Morphogenetic Protein Signaling
}

\author{
Kevin T. Eade and Douglas W. Allan \\ Department of Cellular and Physiological Sciences, University of British Columbia, Vancouver, British Columbia, Canada V6T 1Z3
}

\begin{abstract}
The terminal differentiation of many developing neurons occurs after they innervate their target cells and is triggered by secreted target-derived signals that are transduced by presynaptic cognate receptors. Such retrograde signaling induces the expression of genes that are often distinctive markers of neuronal phenotype and function. However, whether long-term maintenance of neuronal phenotype requires persistent retrograde signaling remains poorly understood. Previously, we demonstrated that retrograde bone morphogenetic protein (BMP) signaling induces expression of a phenotypic marker of Drosophila Tv neurons, the neuropeptide FMRFamide (FMRFa). Here, we used a genetic technique that spatiotemporally targets transgene expression in Drosophila to test the role of persistent BMP signaling in the maintenance of Tv phenotype. We show that expression of dominant blockers of BMP signaling selectively in adult Tv neurons dramatically downregulated FMRFa expression. Moreover, adult-onset expression of mutant Glued, which blocks dynein/ dynactin-mediated retrograde axonal transport, eliminated retrograde BMP signaling and dramatically downregulated FMRFa expression. Finally, we found that BMP deprivation did not affect Tv neuron survival and that FMRFa expression fully recovered to control levels after the termination of BMP blockade or Glued expression. Our results show that persistent retrograde BMP signaling is required to induce and to subsequently maintain the expression of a stably expressed phenotypic marker in a subset of mature Drosophila neurons. We postulate that retrograde maintenance of neuronal phenotype is conserved in vertebrates, and as a consequence, neuronal phenotype is likely vulnerable to neurodegenerative disease pathologies that disrupt neuronal connectivity or axonal transport.
\end{abstract}

\section{Introduction}

Maintenance of neuronal phenotype is critical to nervous system function. However, our understanding of the mechanisms that maintain the differentiated state of neurons is rudimentary. Terminal differentiation of many neurons requires retrograde signals from the target cells that they innervate, including bone morphogenetic proteins (BMPs), activins, cytokines, and neurotrophins (Ernsberger and Rohrer, 1999; Nishi, 2003; Hippenmeyer et al., 2004). Target-induced genes are often stably expressed, distinguishing phenotypic markers with critical roles in synaptic transmission, including neuropeptides (Coulombe and Kos, 1997; Patel et al., 2000; Duong et al., 2002; Allan et al., 2003), neurotransmitter biosynthetic enzymes (Ernsberger and

\section{Received Jan. 9, 2009; accepted Feb. 7, 2009.}

This work was supported by operating grants from the Canadian Institutes of Health Research (CIHR) and the EJLB Foundation. All imaging was performed on a confocal microscope that was supported from infrastructure awards from the Canadian Foundation for Innovation and The British Columbia Knowledge Development Fund. D.W.A. is a CIHR New Investigator, a Michael Smith Foundation for Health Research Career Scholar, an EJLB Foundation Investigator, and a Tula Scholar. We gratefully acknowledge Drs. Vanessa Auld, Shernaz Bamji, Timothy O'Connor, Jane Roskams (University of British Columbia, Vancouver, British Columbia, Canada), and Victor May (University of Vermont, Burlington, VT) for their valuable comments, and members of the Allan Laboratory for technical support and intellectual input. We also thank Justin Kumar, Carl-Henrick Heldin, Thomas Schwarz, Stuart Newfeld, Graeme Davis, Paul Taghert, and the Bloomington Drosophila Stock Centre for fly stocks and reagents.

Correspondence should be addressed to Douglas W. Allan, Department of Cellular and Physiological Sciences, Room 2420 Life Sciences Centre, 2350 Health Sciences Mall, University of British Columbia, Vancouver, British Columbia, Canada V6T 1Z3. E-mail: dwallan@interchange.ubc.ca.

D01:10.1523/JNEUROSCI.0213-09.2009

Copyright $\odot 2009$ Society for Neuroscience $\quad$ 0270-6474/09/293852-13\$15.00/0
Rohrer, 1999; Stanke et al., 2006), and ion channels (MartinCaraballo and Dryer, 2002). However, it is currently unclear whether the maintenance of such target-induced genes requires persistent retrograde signaling in the adult nervous system.

Members of the TGF $\beta$ superfamily, including BMPs and activins, are the only known conserved mediators of retrograde neuronal differentiation from Drosophila to vertebrates (Nishi, 2003; Hippenmeyer et al., 2004; Xu and Hall, 2006). In vertebrates, target-derived activin induces the neuropeptide calcitonin gene-related peptide (CGRP) in cutaneous afferents (Ai et al., 1999). Activin retrogradely induces the neuropeptide somatostatin in choroid neurons (Darland and Nishi, 1998). BMP4 acts retrogradely to determine transcription factor expression in trigeminal neurons (Hodge et al., 2007). In Drosophila, targetderived BMP induces expression of neuropeptides, FMRFamide (FMRFa) in Tv neurons (Allan et al., 2003), and dILP7 in subsets of MP2 neurons (Miguel-Aliaga et al., 2008).

In the adult vertebrate nervous system, activin and BMP signaling modulate dendritic spine morphology and synaptic efficacy (Shoji-Kasai et al., 2007; Sun et al., 2007). Moreover, activin is upregulated in the skin after injury and acts retrogradely to increase the number of cutaneous afferents that express CGRP (Xu et al., 2005). However, only indirect evidence supports a role for retrograde TGF $\beta$ superfamily signaling in maintenance of adult neuronal phenotype. Axotomy of adult SCG (superior cervical ganglion) neurons alters their neuropeptide expression profile, an effect that is partially blocked by BMP administration 
(Pavelock et al., 2007). Intriguingly, BMP ligands are expressed at the target tissues of those neurons (V. May, personal communication). Similarly, systemic statins reduce CGRP expression in adult cutaneous afferents in vivo, likely by inhibition of BMP signaling (Bucelli et al., 2008). These results led the authors of both studies to propose that retrograde BMP signaling is required to maintain normal neuropeptide levels.

Here, we directly tested the hypothesis that persistent retrograde BMP signaling maintains adult neuronal phenotype. Previously, we demonstrated that induction of the neuropeptide FMRFa in Drosophila Tv neurons requires target-derived BMP signaling (Allan et al., 2003). Here, by targeting transgenic dominant blockers of BMP signaling selectively in adult Tv neurons, after their normal development, we show that maintenance of FMRFa is absolutely dependent on persistent BMP signaling. Moreover, adult-onset blockade of retrograde axonal transport inhibited nuclear BMP signaling and eliminated FMRFa expression. These data demonstrate that persistent retrograde BMP signaling is required to induce and subsequently maintain the mature phenotype of subsets of Drosophila neurons.

\section{Materials and Methods}

\section{Fly genetics}

Flies were maintained on standard cornmeal food and maintained at stable temperatures in environment rooms set at $70 \%$ humidity at 18,25 , or $29^{\circ} \mathrm{C}$. The following fly strains were used: FMRFa-lacZ (WF3-T2) (Allan et al., 2003); apterous ${ }^{\text {md544 }}$ [referred to as a ${ }^{\text {GAL4 }}$ here (Allan et al., 2003)]; tubP $>G A L 80^{T S}$ [temperature-sensitive GAL80 under the control of the Drosophila tubulin 84B promoter (McGuire et al., 2003)]; UAS$n E G F P$ [nuclear localized enhanced green fluorescent protein (EGFP)]; $U A S-$ wit $^{\Delta I}$ [intracellular domain deletion (McCabe et al., 2003); referred to as $\left.U A S-w i t^{D N}\right] ; U A S-t k v^{\Delta G S K}[$ GS-box and kinase domain deletion (Haerry et al., 1998); referred to here as UAS-tkv $\left.{ }^{D N}\right]$; UAS-Mad ${ }^{1}\left[\mathrm{Mad}^{1}\right.$ mutant that cannot bind DNA (Takaesu et al., 2005); referred to here as $U A S-M a d^{D N}$ ]; UAS-Glued ${ }^{\Delta 84}\left[\right.$ referred to here as UAS-Glued ${ }^{D N}$ (Allen et al., 1999)]; UAS-ANF-GFP [pre-pro-atrial natruietic factor fused to emerald green fluorescent protein (emGFP) (Rao et al., 2001)]. The X chromosome insertion (Rao et al., 2001) was hopped (DWA) to chromosome III using standard methods of P-element mobilization. Flies were generously provided by Paul Taghert, Washington University School of Medicine, St. Louis, MO; Thomas Schwarz, Children's Hospital Boston, Boston, MA; Justin Kumar, Indiana University, Bloomington, IN; Stuart Newfeld, Arizona State University, Tempe, AZ; Graeme Davis, University of California San Francisco, San Francisco, CA; and the Bloomington Drosophila Stock Center (Bloomington, IN).

\section{Spatial and temporal regulation of transgene expression using the} TARGET system

Flies for TARGET-mediated transgene induction (see Figs. 3-7) were generated by crossing $F M R F a-l a c Z, a p{ }^{G A L 4} / C y O$, actin-green fluorescent protein (GFP); tub-GAL80 ${ }^{T S}, U A S-n E G F P$ (see Fig. 3) or ap ${ }^{G A L 4} / C y O$, actin-GFP; tub-GAL80 ${ }^{T S}, U A S-n E G F P$ (see Figs. 4-7) to $w^{1118}$ for the control group or UAS-tkv ${ }^{D N}$;UAS-wit ${ }^{D N}$ (see Figs. 3-6), or UAS-Mad ${ }^{D N}$; $U A S-M a d^{D N}$ (see Figs. 4-6), or UAS-Glued ${ }^{D N}$ (see Fig. 7). Experiments were performed on resulting progeny bearing the appropriate genotypes (screened by loss of the Cyo, actin-GFP chromosome), as detailed in Results. All experimental and control flies were raised at $18^{\circ} \mathrm{C}$ to suppress GAL4/UAS-mediated transgene expression until the first day after eclosion (hatching from the pupal case). Adult flies were collected every $24 \mathrm{~h}$ to ensure accuracy of age for experimental conditions. Noninduced flies were subsequently maintained at $18^{\circ} \mathrm{C}$ for continued suppression of transgene expression for the duration of the experiment. Induced flies were switched to $29^{\circ} \mathrm{C}$ for the entire duration of the induction period indicated, for continuous transgene expression.

\section{Immunohistochemistry and in situ hybridization}

Antibodies. Primary antibodies were as follows: sheep anti-digoxygenin (DIG) (1:100; Roche), mouse anti-Eya (1:100; clone 10H6; Developmen- tal Studies Hybridoma Bank), rabbit anti-GFP (1:100; A6455; Invitrogen), rabbit anti-FMRFa (1:1000; T-4757; Peninsula Laboratories), rabbit anti-pMad (1:1000; a generous gift from C.-H. Heldin, Ludwig Institute for Cancer Research, Uppsala, Sweden), and mouse anti- $\beta$ galactosidase $(1: 100 ; 40-1 \mathrm{a})$. Secondary antibodies were as follows: donkey anti-sheep Alexa 555 (1:10; Invitrogen), and donkey anti-mouse Cy5 and donkey anti-rabbit Cy2 (1:200; Jackson ImmunoResearch).

Antisense DIG-RNA probe. DIG-uracil-tagged RNA probes were generated using T3 RNA polymerase from clone RH03963 (Drosophila Genomics Resource Center, Bloomington, IN) containing a $1584 \mathrm{bp}$ FMRFa cDNA (using the Roche DIG-U-RNA Labeling kit). Probe synthesis was confirmed using gel electrophoresis.

Multiplex fluorescent in situ hybridization and immunohistochemistry. All tissues that were compared for fluorescence intensity were processed at the same time using the same aliquots of all solutions under the same conditions. They were then mounted on the same slide. Adult ventral nerve cords were dissected in ice-cold PBS, and then incubated for 50 min in ice-cold $4 \%$ paraformaldehyde (PFA) in PBTw (PBS, $0.1 \%$ Tween 20, 0.1\% DEPC-treated $\mathrm{ddH}_{2} \mathrm{O}$ ). Samples were then PBTw washed and stored overnight in $100 \%$ methanol at $-20^{\circ} \mathrm{C}$. Samples were rehydrated and placed in 4\% PFA-PBTw for 20 min. Samples were washed in PBTw and incubated in HYBE solution at $55^{\circ} \mathrm{C}$ for $1 \mathrm{~h}$. Hybridization with DIG-tagged antisense RNA probes to FMRFa was performed at $55^{\circ} \mathrm{C}$ overnight on a rotating platform in a Bambino Hybridization Oven. Samples were PBTw washed and incubated for $1 \mathrm{~h}$ in PBTw with 5\% donkey serum (PBTw-DS). Tissues were incubated overnight at $4^{\circ} \mathrm{C}$ in PBTw-DS containing primary antibodies. Tissues were washed (PBTw) and blocked (PBTw-DS), and then incubated in secondary antibody (in PBTw-DS) at room temperature for $3 \mathrm{~h}$. Tissues were washed in PBTw, and then PBS, and slide-mounted in Vectashield (Vector Laboratories).

Immunohistochemistry. Ventral nerve cords were dissected in ice-cold PBS and fixed in ice-cold 4\% PFA in $0.1 \%$ PBT (PBS- $0.1 \%$ Triton $\mathrm{X}-100$ ) for $40 \mathrm{~min}$, washed in PBT, and incubated in PBT with 5\% donkey serum (PBT-DS). Primary antibodies were incubated overnight at $4^{\circ} \mathrm{C}$ and secondary antibodies were incubated at $3 \mathrm{~h}$ at room temperature. Antibodies were incubated in PBT-DS. Tissues were washed in PBT, and then PBS, and mounted in Vectashield (Vector Laboratories).

\section{Image analysis}

All images were acquired on an Olympus FV1000 confocal microscope as multiple TIFF files representing individual $Z$-stacks. For each data set, we quantified every identifiable Th1 and Th3 Tv neuron from each control and experimental animal. Raw files were imported into NIH ImageJ for analysis. For each Tv neuron, we compressed all $Z$-slices spanning whole Tv neurons using the $Z$-projector function, set to sum the pixel intensities from each $Z$-slice. Each Tv neuron was outlined and the mean of the summed pixel intensity for each neuron was measured. Background fluorescence intensity was corrected for by subtracting the average of three regions of background (of equal size to the Tv neuron) from the same summed $Z$-stack for each Tv neuron. The resulting value for each Tv neuron was then incorporated as a single datum point toward the mean FMRFa intensity for each experiment (shown in supplemental Tables $1-3$, available at www.jneurosci.org as supplemental material). To normalize data across multiple time points and genotypes, we further expressed each datum point as a percentage of the mean of the $w^{1118}$ control for that experiment (percentage intensity measurements are provided in supplemental Tables 1-3, available at www.jneurosci.org as supplemental material). For every experiment, we also collected intensity measurements for an additional pair of FMRFa-expressing neurons in Th3 in every nerve cord, using the same settings as for FMRFa in the Tv neurons. These neurons do not show expression for $a p^{\text {GAL4 }}$;UAS-nEGFP and were therefore not subjected to transgene expression. We tabulated the expression of FMRFa in these neurons as internal controls in supplemental Tables 1-3 (available at www.jneurosci.org as supplemental material). These data show that there was no significant difference in the expression of FMRFa in these neurons between different genotypes, regardless of GAL4 induction. For images shown in Figures 1-7, we chose representative images from $\mathrm{Tv}$ neurons that were stacked to show the entire ap 


\section{A larval nerve cord}

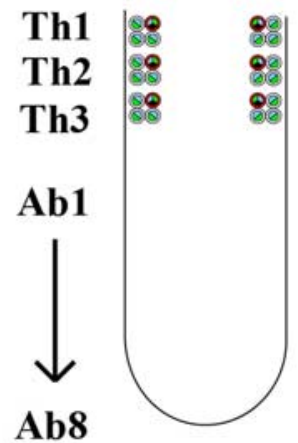

\section{adult nerve cord}

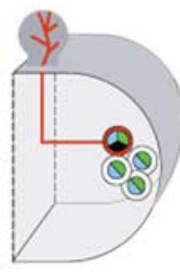

Th3

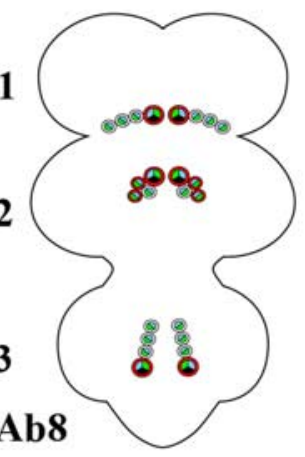

Ab1-Ab8
FMRFa Apterous Eyes absent pMad
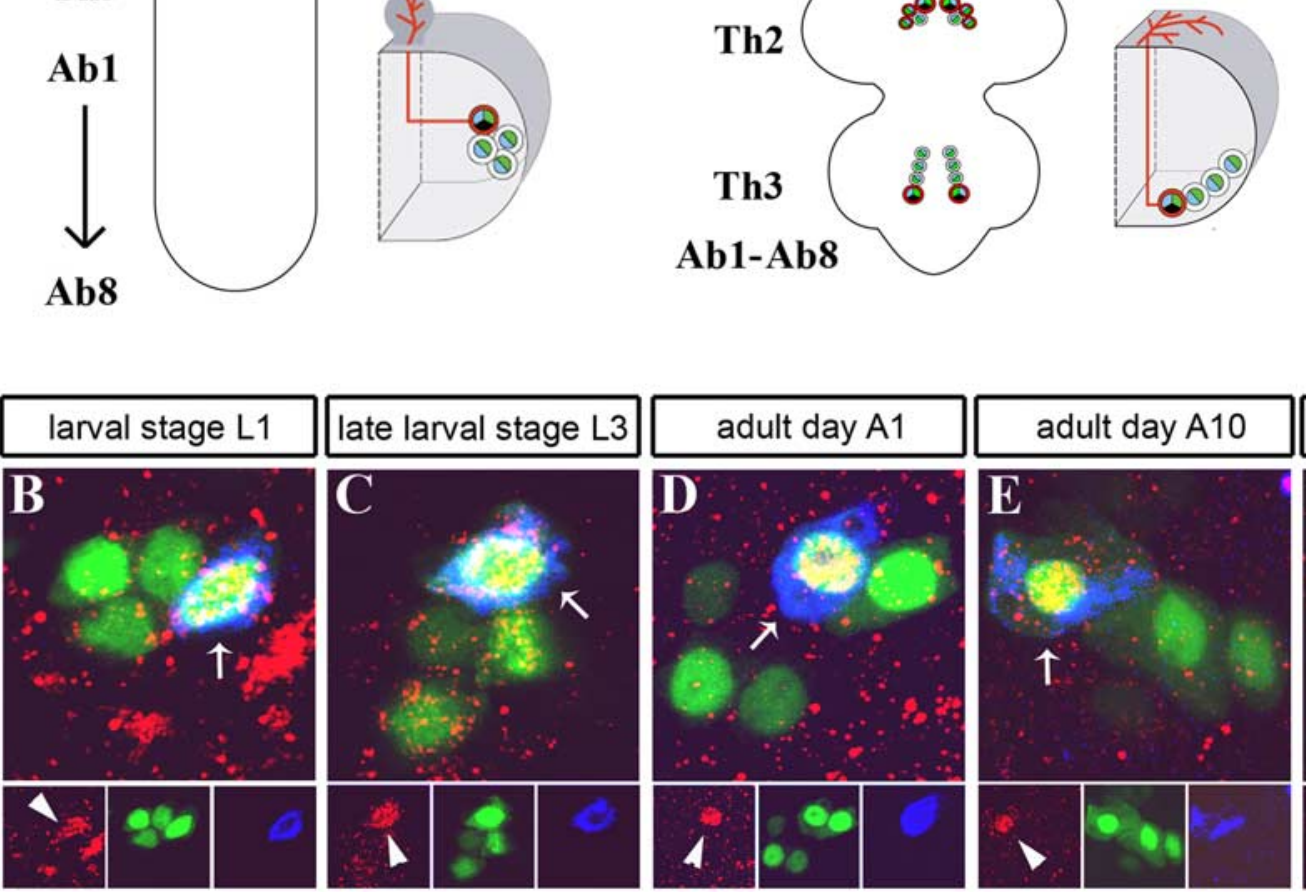

\section{adult day $\mathrm{A} 20$}

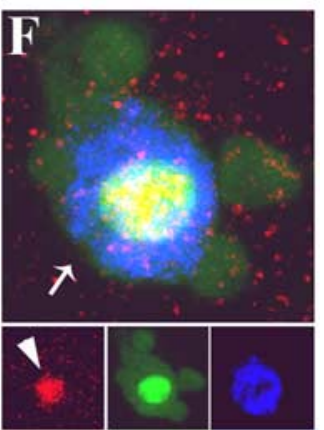

Figure 1. BMP signaling and FMRFa expression persists in Tv neurons throughout larval and adult stages. $A$, Diagrams depicting the larval and adult ventral nerve cord, shown from thoracic segment Th1 to abdominal segment Ab8, and also in a transverse section through thoracic hemisegment Th1, to show the relative position of each Tv cluster and Tv axonal projection. These diagrams show the six thoracic Tv clusters that coexpress the transcription factors apterous (green) and eyes absent (blue) within Th1 to Th3. Each Tv cluster comprises Tv, Tvb, Tva, and Tvc neurons. In larvae, only the Tv neuron expresses FMRFa (red) and nuclear pMad (black), and innervates the DNH. In each thoracic segment, the bilateral Tv neurons innervate the ipsisegmental DNH. In adult Th1 and Th3 segments, only the Tv neuron expresses FMRFa and nuclear pMad. In adult Th2, FMRFa is expressed in Tv, Tva, and Tvc, but only the Tv neuron has nuclear pMad. There are no Tv clusters in abdominal segments, Ab1 to Ab8 in larvae or adults. $\boldsymbol{B}-\boldsymbol{F}$, The Tv neuron (arrow) is identified by coexpression of apterous (green; ap ${ }^{\text {GAL4 }}$,UAS- $n E G F P$ ) and FMRFa (blue; FMRFa-lacZ; anti- $\beta$-Gal) in Tv clusters. Nuclear accumulation of pMad (red; arrowhead; anti-pMad) in the Tv neuron is evident in larval stage L1 (B), late larval stage L3 (C), adult day A1 (D), A10 (E), and A20 (the oldest age examined) $(\boldsymbol{F})$. Flies were maintained at $25^{\circ} \mathrm{C}$.

cluster. Images that were directly compared were further processed in an identical way, simultaneously, using Adobe Photoshop CS2.

\section{Statistical analysis}

Normally distributed unpaired experimental groups data were compared using a two-tailed $t$ test assuming equal variance, to identify significant differences between groups. For data groups that are not normally distributed, we used the nonparametric Mann-Whitney test. Normal distribution was determined using the D'Agostino and Pearson omnibus test. All statistical analysis and graph data were performed using Prism 5 software (GraphPad).

\section{Results}

The Drosophila nervous system contains six Tv neurons, one in each of the six thoracic hemisegments (Th1-3) of the ventral nerve cord (VNC) (Fig. 1A). Before metamorphosis, Tv axons project to the ipsisegmental dorsal neurohemal organ $(\mathrm{DNH})$, which protrudes dorsally from each thoracic VNC segment (Benveniste et al., 1998; Allan et al., 2003). In adults, after DNH retraction into the VNC, Tv axons form neurohaemal contacts along the dorsal VNC neural sheath (Lundquist and Nässel, 1990; Brown et al., 2006). Developing and adult Tv neurons are phenotypically characterized by expression of the neuropeptide FMRFa (O’Brien et al., 1991; Schneider et al., 1991), which they secrete into the hemolymph at neurohemal endings (Predel et al., 2004; Wegener et al., 2006). In each thoracic hemisegment, the Tv neuron is one of a cluster of four neurons that coexpress the transcription factors, apterous and eyes absent, termed the Tv cluster (Benveniste et al., 1998; Miguel-Aliaga et al., 2004). FMRFa expression in Tv neurons is determined by a specific set of transcriptional regulators and target (DNH)-derived BMP signaling (Allan et al., 2003, 2005; Miguel-Aliaga et al., 2004). Tv axons access the BMP ligand, Glass bottom boat (Gbb), at the DNH. Gbb engages the type II BMP receptor Wishful thinking (Wit) and the type I BMP receptors, Thickveins (Tkv) and Saxophone (Sax), resulting in type I receptor-mediated Mad phosphorylation (pMad) in Tv neurons (Allan et al., 2003; Marqués et al., 2003). Retrograde trafficking of the BMP signal, by an unknown mechanism, translocates pMad to the Tv neuron nucleus, where it induces FMRFa expression (Allan et al., 2003).

\section{BMP signaling persists in mature Tv neurons}

To test whether BMP signaling is maintained in Tv neurons beyond the developmental period, we examined pMad immunoreactivity in the nuclei of larval and adult Tv neurons (Allan et al., 2003). Tv neurons were identified by coexpression of FMRFa 

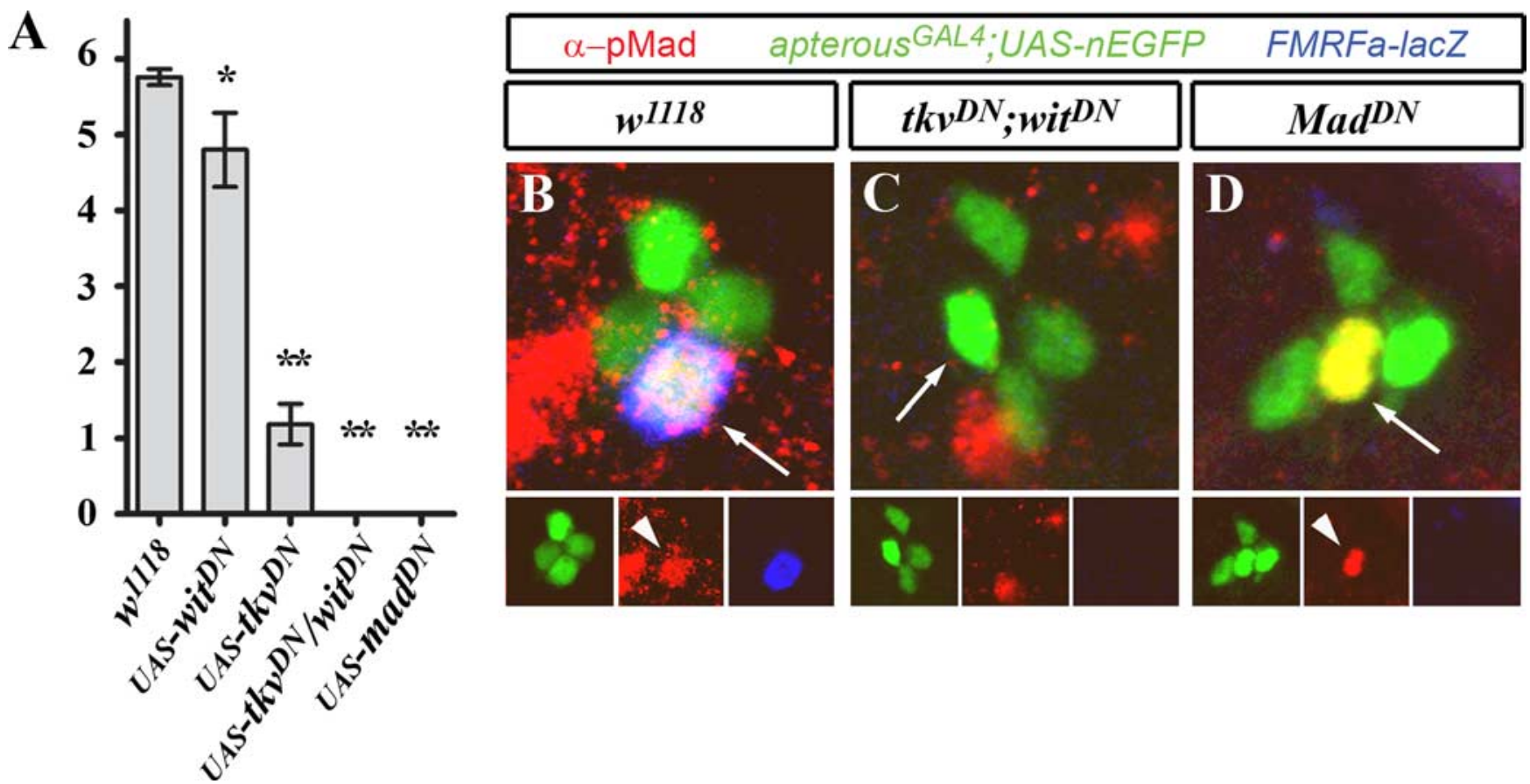

Figure 2. Larval expression of dominant-negative Mad and dominant-negative BMP receptors blocked FMRFa expression in Tv neurons. A, Quantification of Tv neurons that express FMRFa-lacZ (anti- $\beta$ Gal) in L1 larvae. There are six Tv neurons per nerve cord. In $w^{1718}$ control larvae (FMRFa-lacZ,apterous ${ }^{G A L 4} /+$ ), FMRFa expression was seen in all Tv neurons (arrows). We used apterous ${ }^{G A L 4}$ to express dominant-negative BMP pathway transgenes in the Tv cluster and counted the number of Tv neurons in which FMRFa-lacZ was expressed. Expression of dominant-negative BMP type II receptor, wishful thinking (UAS-wit $\left.{ }^{D N}\right)$, caused a small, significant reduction in FMRFa expression $\left({ }^{*} p<0.01\right)$. Dominant-negative BMP type I receptor thickveins $\left(\right.$ UAS-tkv $\left.{ }^{D N}\right)$ caused a great reduction in FMRFa expression. FMRFa expression was $100 \%$ eliminated by coexpression of UAS-tkv ${ }^{D N}$ and UAS-wit ${ }^{D N}$ or by expression of two copies of a dominant-negative version of the BMP-dependent transcription factor, Mad (UAS-Mad ${ }^{D N} ;$ UAS-Mad ${ }^{D N}$ ). ${ }^{* *} p<0.0001$. Error bars indicate SEM. B-D, ap-expressing neurons were identified by apterous ${ }^{G A L 4}$-mediated expression of UAS-nEGFP (green). FMRFa-lacZ expression was determined using anti- $\beta$ Gal (blue). Immunoreactivity to $\mathrm{pMad}$ (red) showed its accumulation in Tv neuron nuclei (arrowhead), indicative of active BMP signaling. $\boldsymbol{B}$, In $w^{1118}$ controls, nuclear pMad accumulation was always observed in FMRFa-expressing Tv neurons. C, Coexpression of dominant-negative BMP receptors UAS-tkv ${ }^{D N}$; UAS-wit ${ }^{D N}$ resulted in $100 \%$ loss of FMRFa-lacZ and nuclear pMad in the Tv cluster. There was no loss of Tv cluster neurons. D. Expression of UAS-Mad ${ }^{\text {DN }}$ resulted in $100 \%$ loss of FMRFa-lacZ expression, but nuclear pMad was unaffected, indicating that BMP pathway activity was unaffected upstream of nuclear pMad accumulation. For details, see text.

(FMRFa-lacZ reporter) and apterous (apterous ${ }^{\text {GAL4 }}$; UAS$n E G F P$ ) (Allan et al., 2003). We observed strong immunoreactivity to pMad in Tv nuclei at all ages tested up to adult day 20 (Fig. $1 B-F)$, the last day tested. These data indicate that a BMP signal is transduced and trafficked into Tv neuronal nuclei through the life of the fly.

\section{Transgenic blockade of BMP signaling in Tv neurons}

We tested the efficacy of numerous transgenes to ablate BMP signaling in Tv neurons. In control L1 larvae $\left(a p^{G A L 4} /+\right.$; UAS$n E G F P /+)$, FMRFa was expressed by $5.7 \pm 0.1$ Tv neurons per VNC ( $n=29 \mathrm{VNCs})$, and nuclear pMad was observed in $100 \%$ of Tv neurons that expressed FMRa ( $n=44$ Tv neurons) (Fig. $2 A, B)$. Using $a p^{G A L 4}$ to express transgenic blockers of BMP signaling in the Tv cluster, we found that coexpression of dominantnegative versions of thickveins (UAS-tkv ${ }^{D N}$ ) (Haerry et al., 1998) and wishful thinking (UAS-wit ${ }^{D N}$ ) (McCabe et al., 2003) resulted in $100 \%$ loss of both pMad immunoreactivity $(n=34)$ and FMRFa expression $\left(n=10 ; p=3.2 \times 10^{-28}\right)$ in L1 Tv neurons (Fig. $2 A, C)$. Expression of two copies of dominant-negative Mad $\left(U A S-M^{D} d^{D N}\right.$ ) (Takaesu et al., 2005) resulted in 100\% loss of FMRFa expression in Tv neurons $\left(n=10 ; p=3.2 \times 10^{-28}\right)$, whereas pMad immunoreactivity was observed in $100 \%$ of $\mathrm{Tv}$ neurons ( $n=30 \mathrm{Tv}$ neurons) (Fig. $2 A, D)$. $\mathrm{Mad}^{\mathrm{DN}}$ encodes a protein in which DNA binding is disrupted. Thus, our data show that BMP signaling upstream of pMad DNA binding had been maintained, but that DNA binding of pMad is required for FMRFa expression. FMRFa was only partially downregulated by ex- pression of either $U A S-t k v^{D N}$ or $U A S-w i t^{D N}$ alone (Fig. $2 A$ ). In summary, transgenic overexpression of $\mathrm{Mad}^{D N}$ or both $t k v^{D N}$ / $w_{i t}^{D N}$ in the Tv cluster prevented the induction of FMRFa expression in developing Tv neurons.

\section{Temporal regulation of BMP signaling in adult Tv neurons} The TARGET system (McGuire et al., 2003) enables temperature-dependent switching of GAL4/UAS-mediated transgene expression, by use of a temperature-sensitive allele of the yeast GAL4-repressor, GAL80 $\left(\mathrm{GAL} 80^{\mathrm{TS}}\right.$ ) (for details, see Fig. $3 A, D)$. We generated the following genotype to spatiotemporally regulate $t k v^{D N}$ and wit $t^{D N}$ expression in adult Tv neurons in vivo using the TARGET system, FMRFa-lacZ, ap ${ }^{G A L 4} / U A S-t k v^{D N}$; $U A S-n E G F P, t u b>G A L 80^{T S} / U A S-w i t^{D N}$. The $w^{1118}$ control genotype was $a p^{G A L 4} /+; U A S-n E G F P, t u b>G A L 80^{T S} /+$.

The efficacy of adult-onset BMP signaling blockade in Tv neurons was examined by pMad nuclear immunoreactivity and FMRFa-lacZ reporter expression in $w^{1118}$ controls (Fig. $3 B, E, G$ ) and $t k v^{D N}$; wit ${ }^{D N}$ flies (Fig. $3 C, F, H$ ). Flies were raised at $18^{\circ} \mathrm{C}$ up to adult day A1 (first day posteclosion). At that time, $a p^{G A L 4}$ mediated GAL4/UAS activity was repressed by GAL80 ${ }^{\mathrm{TS}}$, as shown by lack of nEGFP expression in the Tv cluster (Fig. $3 B, C$ ); FMRFa-lacZ and nuclear pMad expression was observed in 100\% of Tv neurons in $w^{1118}$ control ( $n=15$ Tv neurons) and $t k v^{D N}$; wit $^{D N}$ flies ( $n=18$ Tv neurons) (Fig. $\left.3 B, C\right)$.

At A1, we switched flies to $29^{\circ} \mathrm{C}$ to induce GAL4 activity. After both 12 and $48 \mathrm{~h}$ at $29^{\circ} \mathrm{C}$, we observed robust nEGFP expression in both genotypes (Fig. 3E-G). In $w^{1118}$ controls, FMRFa-lacZ 
A

\section{$18^{\circ} \mathrm{C}$ - no induction}
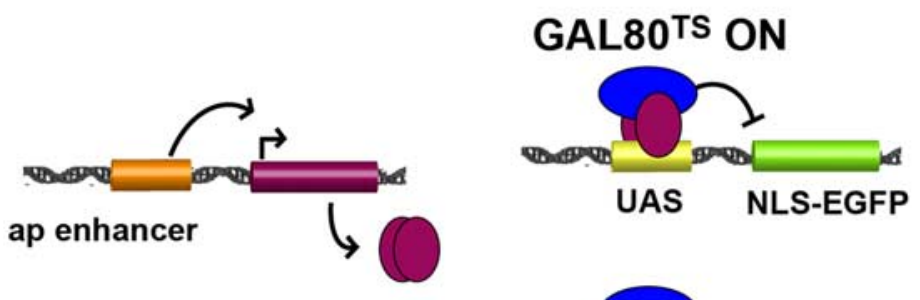

GAL4

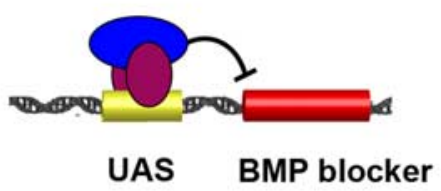

$\alpha$-pMad ap GAL4;UAS-nEGFP FMRFa-lacZ

$w^{1118} t k^{D N} ; w i t^{D N}$

D

$29^{\circ} \mathrm{C}$ - induction

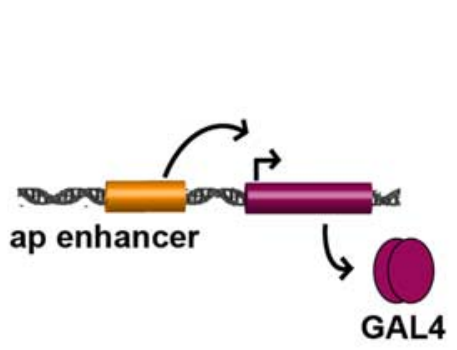

GAL80TS OFF
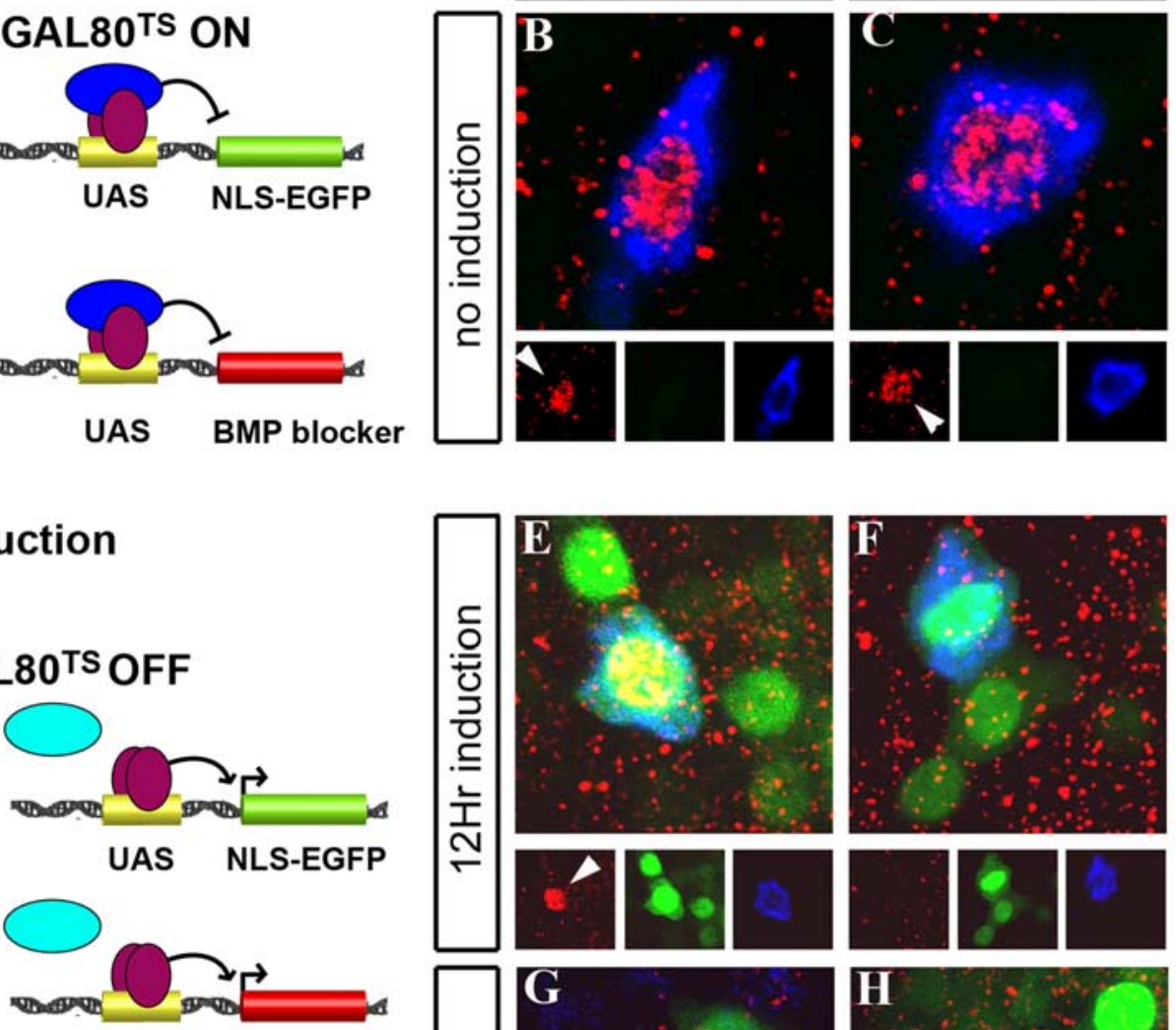

UAS BMP blocker
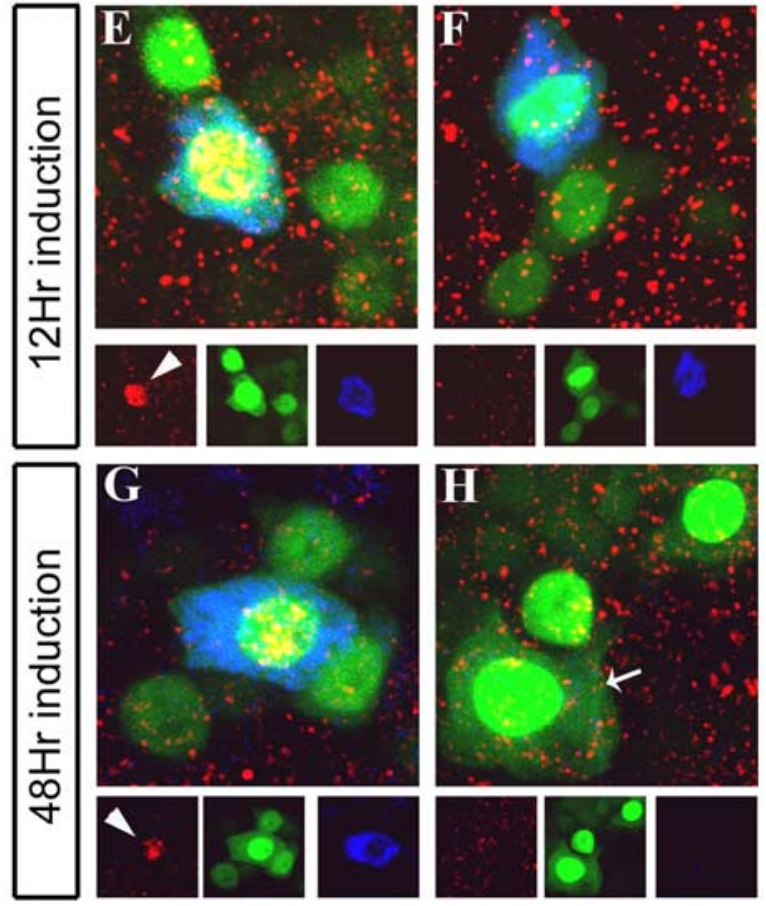

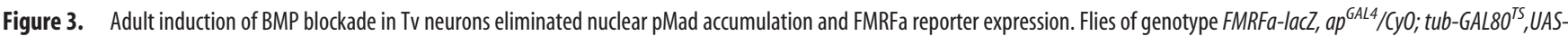

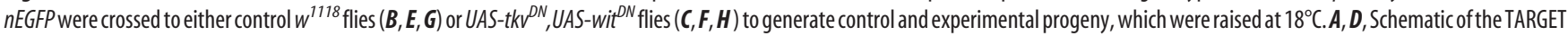
system for regulated spatiotemporal expression of transgenes in the Tv cluster. GAL4 was expressed selectively in all ap neurons under control of the genomic apterous enhancer. GAL $80^{\mathrm{TS}}$ was expressed ubiquitously by the tubulin promoter. $A, A t 18^{\circ} \mathrm{C}, \mathrm{GAL} 4$ activity is not induced; $G A L 80^{\mathrm{TS}}$ binds $\mathrm{GAL} 4$ and blocks GAL4-mediated gene transactivation from UAS sites. $D$, At $29^{\circ} \mathrm{C}, \mathrm{GAL} 4$ activity is induced; loss of GAL $80{ }^{\mathrm{TS}}$ binding to GAL4 allows GAL4 to transactivate gene expression from UAS sites, in this case in all ap neurons, including the Tv cluster. $\boldsymbol{B}, \boldsymbol{C}$, No induction: In adult day A1 animals raised at $18^{\circ} \mathrm{C}, \mathrm{GAL} 80^{\mathrm{TS}}$ blocked $a{ }^{G A L 4}$-mediated induction of UAS-nEGFP (green) and UAS-tkv ${ }^{D N} / U A S$-wit ${ }^{D N}$ (in C). Note lack of nEGFP expression in both genotypes. In $w^{1718}$ control flies (B) and UAS-tkV $v^{D N}$ UAS-wit ${ }^{D N}$ flies (C), there was no difference in the expression of FMRFa-lacZ (blue; anti- $\beta$ Gal) or nuclear pMad (red; anti-pMad; arrowhead) in Tv neurons. For details, see text. $\boldsymbol{E}$, $\boldsymbol{F}$, After $12 \mathrm{~h}$ induction at $29^{\circ} \mathrm{C}$, nEGFP expression was activated (green) in both genotypes. $\boldsymbol{E}$, FMRFa-lacZ and nuclear pMad (arrowhead) expression was maintained in Tv neurons in $w^{1718}$ control flies. $F$, Nuclear accumulation of pMad was completely lost in UAS-tk ${ }^{D N}$;UAS-wit ${ }^{\text {N }}$ flies. FMRFa-lacZ was unaffected by $12 \mathrm{~h}$ induction. These data show that the BMP pathway had been blocked within $12 \mathrm{~h}$ of $\mathrm{GAL} 4$ induction. $\mathbf{G}, \boldsymbol{H}$, After $48 \mathrm{~h}$ induction at $29^{\circ} \mathrm{C}, \mathrm{BMP}$ pathway blockade in UAS-tkV ${ }^{\mathrm{DN}}, U A S-w i t^{D N}$ flies $(\boldsymbol{H})$ resulted in a loss of pMad nuclear accumulation and a profound downregulation of FMRFa-lacZ in Tv neurons (arrow). In $w^{1118}$ control flies (G), nuclear pMad (arrowhead) and FMRFa-lacZ expression were unaffected.

and nuclear pMad expression was observed in $100 \%$ of Tv neurons after 12 and $48 \mathrm{~h}$ at $29^{\circ} \mathrm{C}(12 \mathrm{~h} ; n=16 \mathrm{Tv}$ neurons; $48 \mathrm{~h} ; n=$ 24 Tv neurons) (Fig. $3 E, G)$. In contrast, in $t k v^{D N} ;$ wit ${ }^{D N}$ flies, we observed $100 \%$ loss of pMad nuclear immunoreactivity at $12 \mathrm{~h}$ ( $n=16 \mathrm{Tv}$ neurons) (Fig. $3 F)$ and $48 \mathrm{~h}(n=17 \mathrm{Tv}$ neurons) (Fig. $3 H)$. In $t k v^{D N} ;$ wit ${ }^{D N}$ flies, FMRFa-lacZ was maintained at $12 \mathrm{~h}$ (Fig. $3 F$ ) but was profoundly reduced in $100 \%$ of Tv neurons by 48 h (Fig. $3 H$ ).

In summary, the TARGET system provides robust spatial and temporal regulation of transgene expression in Tv neurons. We found that adult-onset blockade of BMP signaling ablated nuclear pMad immunoreactivity within $12 \mathrm{~h}$ in Tv neurons, and greatly reduced an FMRFa reporter in Tv neurons within $48 \mathrm{~h}$.

BMP blockade in adults dramatically reduced FMRFa transcript and peptide

Using the TARGET system, we tested the effect of adult-onset BMP blockade in Tv neurons on levels of FMRFa transcript [flu- 


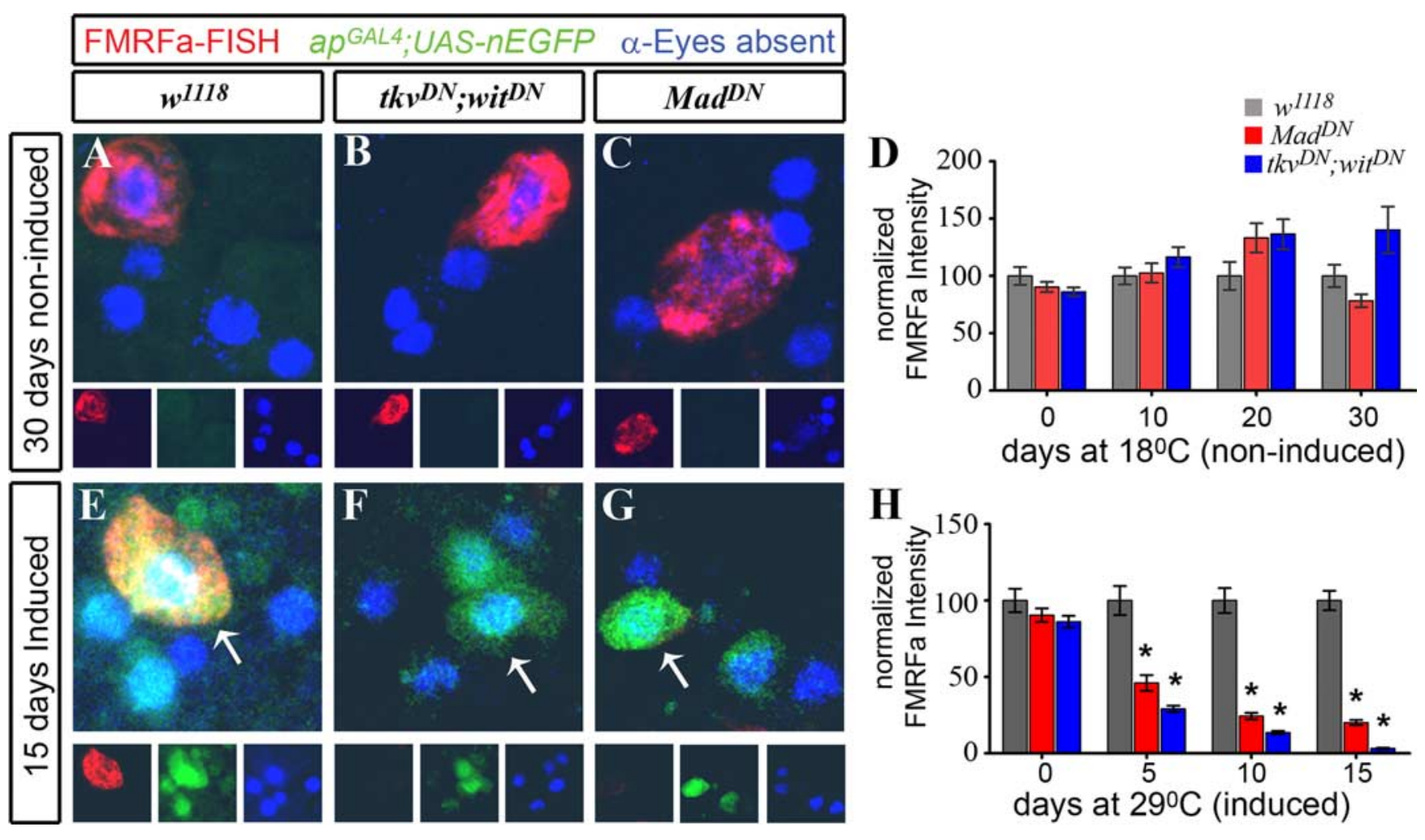

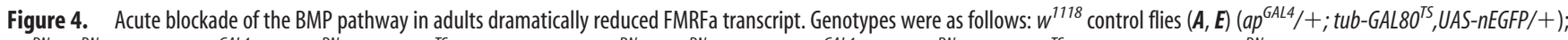

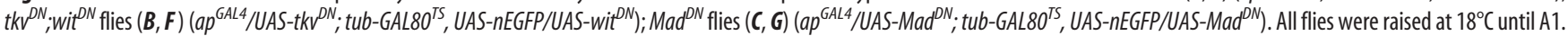
On day $A 1$, flies were subsequently kept at $18^{\circ} \mathrm{C}$ for up to $30 \mathrm{~d}(\boldsymbol{A} \boldsymbol{D})$, or switched to $29^{\circ} \mathrm{C}$ for up to $15 \mathrm{~d}(\boldsymbol{E}-\boldsymbol{H})$. $\boldsymbol{D}, \boldsymbol{H}$, Experimental results comparing relative pixel intensity of FMRFa FISH at each time point, for each genotype. Each datum point was normalized to the percentage of the mean of the $w^{1118}$ control for each time point. Data for each genotype, at each time point, is presented as mean \pm SEM. For details, see supplemental Table 1 (available at www.jneurosci.org as supplemental material). $\boldsymbol{A}-\boldsymbol{C}$, In noninduced flies maintained at $18^{\circ} \mathrm{C}$ for $30 \mathrm{~d}$, GAL4 activity was repressed, as shown by lack of nEGFP (green) expression in Tv cluster neurons (anti-Eyes absent; blue). High-level FMRFa FISH (red; anti-DIG) was observed in control $w^{1718}$ flies $(\boldsymbol{A})$, tkv ${ }^{D N}$; wit ${ }^{D N}$ flies $(\boldsymbol{B})$, and $\mathrm{Mad}^{\mathrm{DN}}$ flies (C). D, Quantification of FMRFa FISH intensity for flies kept at $18^{\circ} \mathrm{C}$, at $\mathrm{A} 1$ (time 0 ), and at 10,20 , and $30 \mathrm{~d}$ later. No significant difference was observed between genotypes at any time point. $\mathbf{E}-\mathbf{G}$, In induced flies maintained at $29^{\circ} \mathrm{C}$ for $15 \mathrm{~d}$, GAL4 activity was induced, as shown by nEGFP expression (green) in Tv cluster neurons (anti-Eyes absent; blue). FMRFa FISH (red) in Tv neurons (arrows) was observed in $w^{1118}$ control flies $(\boldsymbol{E})$ but was severely reduced in $t k v^{D N} ;$ wit $^{D N}(\boldsymbol{F})$ and $M a d^{D N}$ flies $(\boldsymbol{G})$. $\boldsymbol{H}$, Quantification of FMRFa FISH intensity for flies induced at $29^{\circ} \mathrm{C}$, at $\mathrm{A1}$ (time 0 ), and at 5, 10, and $15 \mathrm{~d}$ later. Over the induction period, there was a progressive, dramatic reduction of FMRFa transcript levels after BMP pathway blockade until it was almost entirely absent. ${ }^{*} p<$ 0.0001 compared with control at each time point.

orescent in situ hybridization (FISH)] (Fig. 4) and FMRFa peptide (anti-FMRFa immunofluorescence) (Fig. 5). To quantify FMRFa expression, we measured the relative pixel intensity of FISH or immunofluorescence in Tv soma in all genotypes for each experiment (tabulated in supplemental Tables 1, 2, available at www.jneurosci.org as supplemental material). Data acquisition and quantification are described in Materials and Methods. To standardize our results across multiple time points, here we have expressed FMRFa fluorescence per Tv neuron as a percentage of the mean of the $w^{1118}$ control for each experiment.

We examined FMRFa expression in noninduced flies, maintained at $18^{\circ} \mathrm{C}$, at 10,20 , and $30 \mathrm{~d}$ after $\mathrm{A} 1$. In these noninduced flies, GAL4 activity was blocked at all time points, as shown by lack of nEGFP expression (Figs. $4 A-C, 5 A-C$ ). Strong FMRFa FISH (Fig. $4 A-C$ ) and peptide immunoreactivity (Fig. $5 A-C$ ) was observed in noninduced flies of all genotypes, at all time points. Quantification of FISH (Fig. 4D) and peptide immunoreactivity (Fig. 5D) showed that there was no significant difference in FM$\mathrm{RFa}$ levels between genotypes at each time point. Thus, genotype alone, in the absence of GAL4 induction, had no effect on FMRFa expression.

We next examined FMRFa FISH (Fig. $4 E-H$ ) and peptide immunoreactivity (Fig. $5 E-H$ ) in $w^{1118}$ controls, $t k v^{D N}$; wit ${ }^{D N}$ flies, and $\mathrm{Mad}^{\mathrm{DN}}$ flies that had been switched to $29^{\circ} \mathrm{C}$ at $\mathrm{Al}$, and then maintained at $29^{\circ} \mathrm{C}$ for 5,10 , and $15 \mathrm{~d}$. These ages are comparable with noninduced flies at 10,20, and $30 \mathrm{~d}$; flies maintained at $18^{\circ} \mathrm{C}$ age at about one-half the rate of flies at $29^{\circ} \mathrm{C}$. Flies switched to $29^{\circ} \mathrm{C}$ expressed nEGFP in the Tv cluster (Figs. $4 E-G$, $5 E-G)$. After $15 \mathrm{~d}$ at $29^{\circ} \mathrm{C}, w^{1118}$ controls had high level FMRFa FISH $(100 \pm 6.4 \% ; n=30)$ (Fig. $4 E$ ) and peptide immunofluorescence ( $100 \pm 8.8 \% ; n=45)$ (Fig. $5 E$ ). In contrast, expression of $t k v^{D N} ;$ wit ${ }^{D N}$ for $15 \mathrm{~d}$ at $29^{\circ} \mathrm{C}$ ablated FMRFa transcript to $3.2 \pm$ $0.5 \%$ of $w^{1118}$ controls $\left(n=18\right.$ Tv neurons; $\left.p=2.5 \times 10^{-15}\right)$ (Fig. $4 F)$ and ablated FMRFa immunofluorescence to $8.2 \pm 2.7 \%$ of $w^{1118}$ controls $\left(n=36\right.$ Tv neurons; $\left.p=6.4 \times 10^{-14}\right)$ (Fig. $\left.5 F\right)$. Similarly, expression of $\mathrm{Mad}^{\mathrm{DN}}$ for $15 \mathrm{~d}$ at $29^{\circ} \mathrm{C}$ greatly reduced FMRFa transcript to $20.1 \pm 1.6 \%$ of $w^{1118}$ controls $(n=32 \mathrm{Tv}$ neurons; $p=2.5 \times 10^{-18}$ ) (Fig. $4 G$ ) and reduced FMRFa immunofluorescence to $37.9 \pm 4.6 \%$ of $w^{1118}$ controls $(n=32 \mathrm{Tv}$ neurons; $p=3.6 \times 10^{-7}$ ) (Fig. $\left.5 G\right)$.

We further quantified FMRFa transcript and peptide levels in $w^{1118}$ control, $t k^{D N} ; w i t^{D N}$, and $\mathrm{Mad}^{D N}$ flies after 5 and $10 \mathrm{~d}$ at $29^{\circ} \mathrm{C}$ (Figs. $4 \mathrm{H}, 5 \mathrm{H}$; supplemental Tables 1, 2, available at www. jneurosci.org as supplemental material). We observed a dramatic decline of transcript levels after induction of BMP blockade at A1. In $t k v^{D N}$; wit ${ }^{D N}$ flies, FMRFa transcript levels fell 3.5-fold by day 5, 7.4 -fold by day 10 , and 30 -fold by day 15 , when compared with $w^{1118}$ controls (Fig. $4 H$ ). Furthermore, FMRFa peptide levels fell 


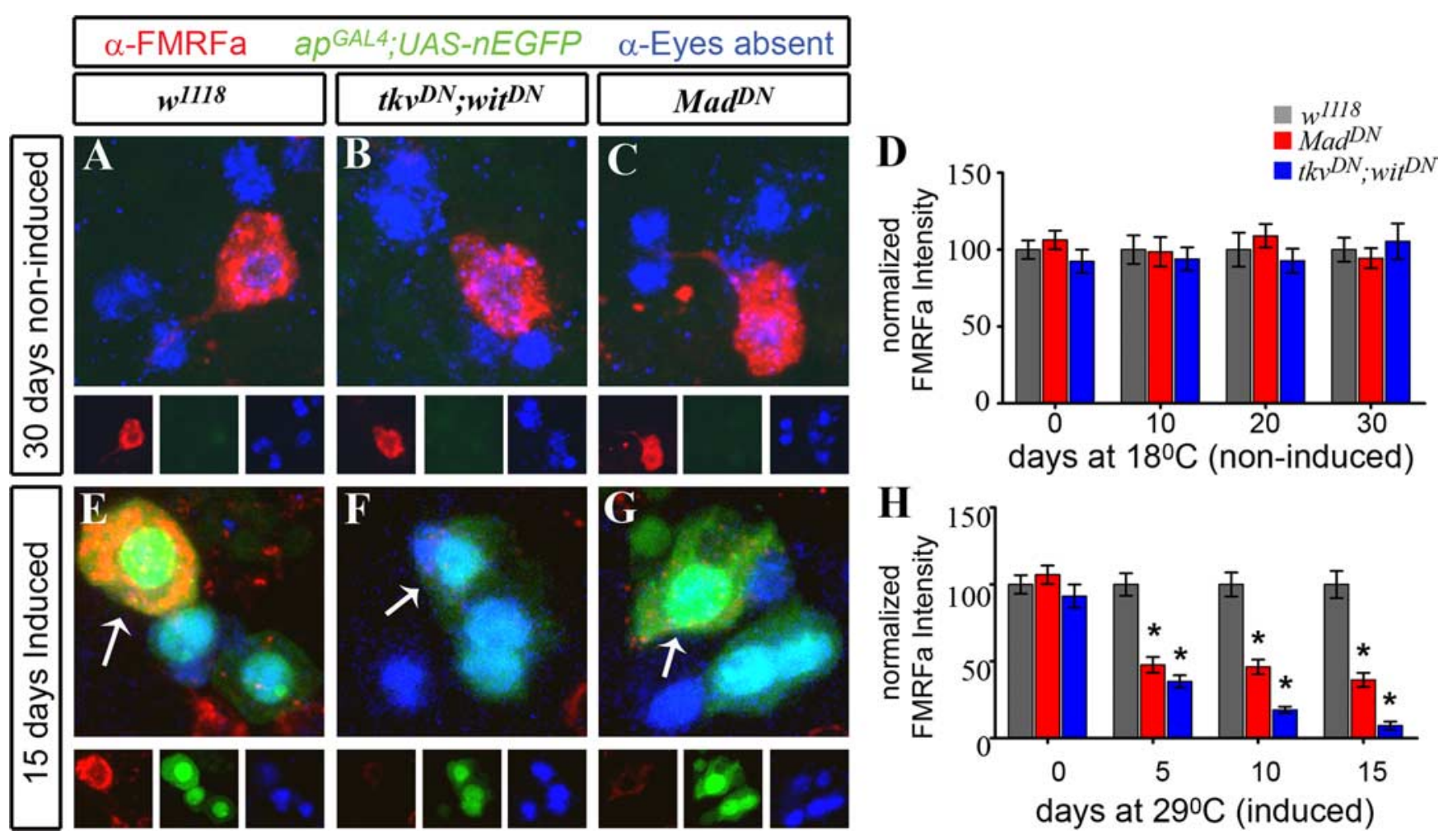

Figure 5. Acute blockade of the BMP pathway in adults dramatically reduced FMRFa peptide. Genotypes were as follows: $w^{1118}$ control flies $(\boldsymbol{A}, \boldsymbol{E})\left(a p^{6 A L 4} /+;\right.$; tub-GAL80 ${ }^{\text {TS }}$,UAS-nEGFP/+ $)$;

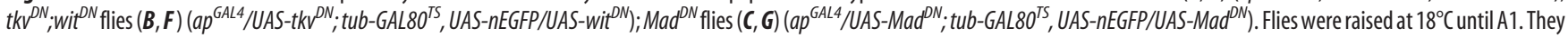
were then kept at $18^{\circ} \mathrm{C}$ for up to $30 \mathrm{~d}(\boldsymbol{A}-\boldsymbol{D})$, or switched to $29^{\circ} \mathrm{C}$ for up to $15 \mathrm{~d}(\boldsymbol{E}-\boldsymbol{H})$. $\boldsymbol{D}, \boldsymbol{H}$, Experimental results comparing relative pixel intensity of FMRFa immunoreactivity at each time point, for each genotype. Each datum point was normalized to the percentage of the mean of the $W^{1118}$ control at each time point. Data for each genotype at each time point are presented as mean \pm SEM. For details, see supplemental Table 2 (available at www.jneurosci.org as supplemental material). $\boldsymbol{A}-\boldsymbol{C}$, In noninduced flies maintained at $18^{\circ} \mathrm{C}$ for $30 \mathrm{~d}, \mathrm{GAL} 4$ activity was repressed, as shown by lack of nEGFP (green) expression in Tv cluster neurons (anti-Eyes absent; blue). High-level FMRFa immunoreactivity (red; anti-FMRFa) was observed in $\operatorname{control}^{1718}$ flies $(\boldsymbol{A})$, tkv $v^{D N}$; wit ${ }^{D N}$ flies $(\boldsymbol{B})$, and $\mathrm{Mad}^{\mathrm{DN}}$ flies (C).D, Quantification of FMRFa immunoreactivity intensity for flies kept at $18^{\circ} \mathrm{C}$, at $\mathrm{A} 1$ (time 0 ), and at 10,20 , and $30 \mathrm{~d}$ later. No significant difference was observed between genotypes at any time point. $\mathbf{E}-\mathbf{G}$, In induced flies maintained at $29^{\circ} \mathrm{C}$ for $15 \mathrm{~d}$, GAL4 activity was induced, as shown by nEGFP expression (green) in Tv cluster neurons (anti-Eyes absent; blue). FMRFa immunoreactivity (red) in Tv neurons (arrows) was observed in $w^{1118}$ control flies $(\boldsymbol{E})$, but was severely reduced in $t k v^{D N} ;$ wit ${ }^{D N}(\boldsymbol{F})$ and $M a d^{D N}$ flies $(\boldsymbol{G})$. $\boldsymbol{H}$, Quantification of FMRFa immunoreactivity intensity for flies induced at $29^{\circ} \mathrm{C}$, at $\mathrm{A} 1$ (time 0 ), and at 5,10 , and $15 \mathrm{~d}$ later. Throughout the induction period, there was a progressive, dramatic reduction of FMRFa peptide levels after BMP pathway blockade until it was almost entirely absent. ${ }^{*} p<0.0001$ compared with control at each time point.

3-fold by day 5, 5.4-fold by day 10 , and 12 -fold by day 15 , when compared with $w^{1118}$ controls (Fig. $5 H$ ). In $\mathrm{Mad}^{D N}$ flies, FMRFa transcript levels fell 2.2 -fold by day 5,4 .1-fold by day 10 , and 5 -fold by day 15, when compared with $w^{1118}$ controls (Fig. 4H). Furthermore, FMRFa peptide levels fell 2.1-fold by day 5, 2.2-fold by day 10 , and 2.6 -fold by day 15 , when compared with $w^{1118}$ controls (Fig. $5 H$ ).

We confirmed that loss of BMP signaling in adult Tv neurons did not cause gross retraction of Tv axons from their terminal field. We expressed a transgenic marker of dense-core vesicles, atrial natruietic factor (UAS-ANF-emGFP) (Rao et al., 2001) in Tv cluster neurons (using $a p^{G A L 4}$ ) in $w^{1118}$ control, $t k v^{D N}$; wit ${ }^{D N}$, and $\mathrm{Mad}^{D N}$ flies. After $15 \mathrm{~d}$ of induction at $29^{\circ} \mathrm{C}$, we found that Tv axonal projections were normal in all genotypes (supplemental Fig. 1, available at www.jneurosci.org as supplemental material), showing that Tv axons had not retracted.

In summary, we show that maintenance of FMRFa expression in adult Tv neurons requires persistent BMP signaling. Interestingly, the decline of FMRFa peptide closely parallels that of FM$\mathrm{RFa}$ transcript. The simplest explanation is that FMRFa peptide is rapidly translated and trafficked to Tv axon termini for secretion into the hemolymph, and that a high level of FMRFa transcription is required to maintain that.
Restoration of FMRFa transcript after recovery from acute BMP blockade in adults

We tested the capacity of Tv neurons to restore FMRFa transcript after a period of BMP blockade. We raised $w^{1118} \operatorname{control}, t k v^{D N}$; $w_{i t}{ }^{D N}$, and $M a d^{D N}$ flies at $18^{\circ} \mathrm{C}$ until Al. They were switched to $29^{\circ} \mathrm{C}$ for $10 \mathrm{~d}$ to induce GAL4 activity, and reduce FMRFa transcript $\left(\sim 13\right.$ and $\sim 24 \%$ of $w^{1118}$ control levels in $t k v^{D N} ; w i t^{D N}$ and $\mathrm{Mad}^{D N}$ flies, respectively) (Figs. $4 H, 6 A-D$; supplemental Table 1 , available at www.jneurosci.org as supplemental material). Flies were then returned to $18^{\circ} \mathrm{C}$ for an additional $10 \mathrm{~d}$ of "recovery," in which GAL4 no longer drove transgene expression and transgene levels presumably decline. Remarkably, after recovery, FMRFa FISH levels in $t k v^{D N} ;$ wit ${ }^{D N}$ and $\mathrm{Mad}^{D N}$ flies was fully restored to control levels (Fig. 6E-H; supplemental Table 1, available at www.jneurosci.org as supplemental material). In $w^{1118}$ controls, FMRFa FISH intensity was $100 \pm 7.3 \%$ of the mean of $w^{1118}$ controls ( $n=53 \mathrm{Tv}$ neurons). In $t k v^{D N} ; w i t^{D N}$ flies, FMRFa FISH was $109.8 \pm 10.3$ [ $n=53$ Tv neurons; no significant difference to control (NSD)] (Fig. 6F). In $\mathrm{Mad}^{D N}$ flies, FMRFa intensity was $111.2 \pm 7.4 \%(n=53$ Tv neurons; NSD) (Fig. $6 G)$. We noted a weak persistent EGFP expression in the Tv cluster in "recovered" flies (Fig. $6 E-G$ ), confirming that transgene expression had been induced previously. 


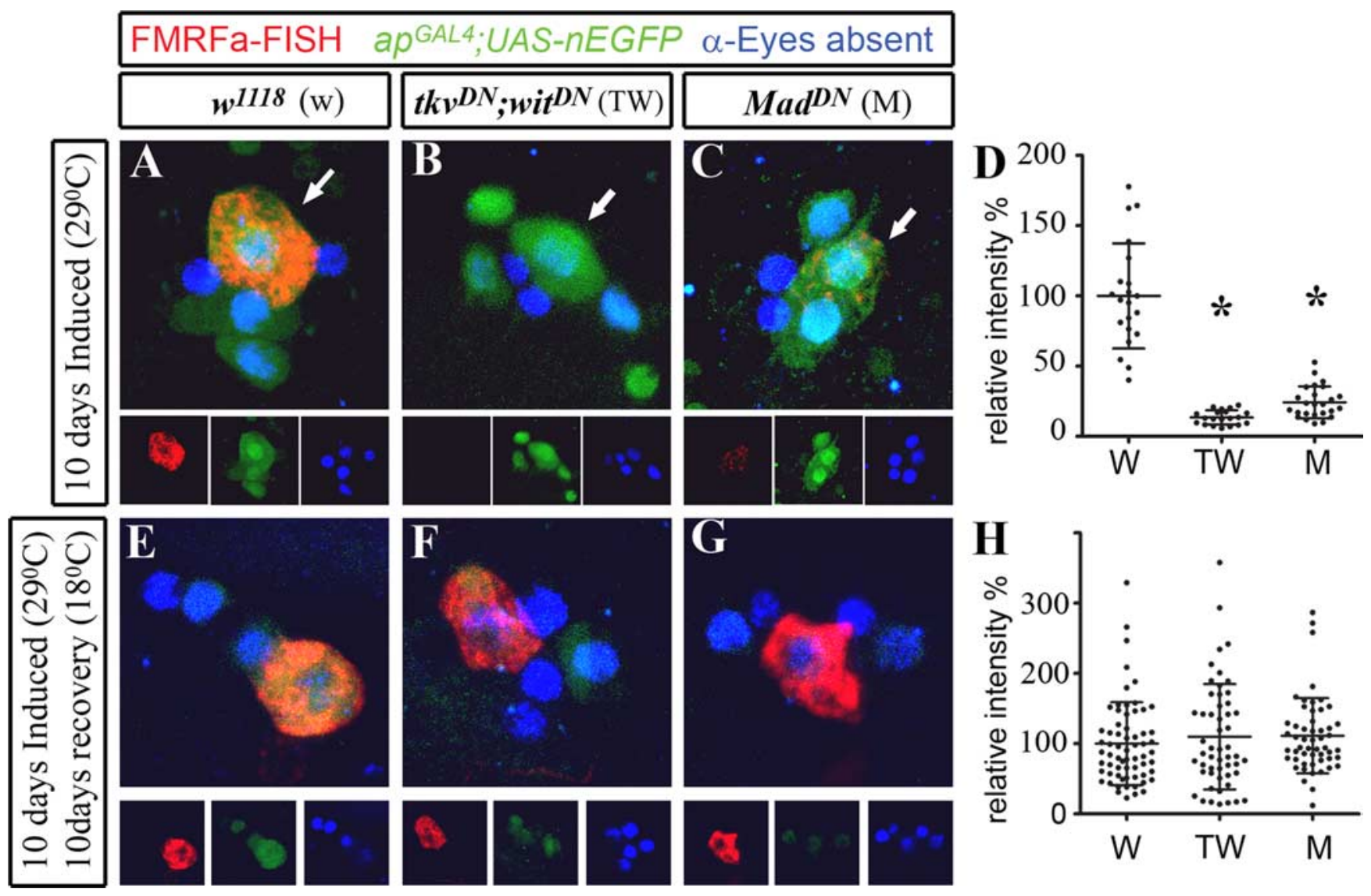

Figure 6. FMRFa transcript was fully restored after recovery from acute BMP blockade in adults. Genotypes were as follows: $w^{1118}$ control flies $(A, E)\left(a p^{G A L 4} /+;\right.$ tub-GAL80 ${ }^{\text {TS }}$,UAS-nEGFP/ + );

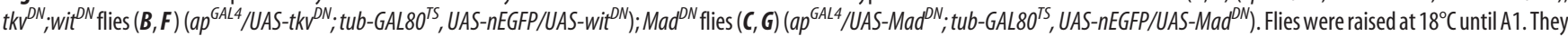
were then switched to $29^{\circ} \mathrm{C}$ to induce GAL4 activity for $10 \mathrm{~d}(\boldsymbol{A}-\boldsymbol{D})$, or switched to $29^{\circ} \mathrm{C}$ for $10 \mathrm{~d}$ to induce GAL 4 activity $(\boldsymbol{E}-\boldsymbol{H})$, and then returned to $18^{\circ} \mathrm{C}$ for $10 \mathrm{~d}$ to allow neurons to recover from BMP blockade. D, $\boldsymbol{H}$, Scatter plots show relative pixel intensity of FMRFa FISH in individual Tv neurons of $w^{1118}$ control $(\mathrm{w}), t_{k}{ }^{D N}$; wit ${ }^{D N}$ flies (TW), or Mad ${ }^{D N}$ flies (M). FMRFa FISH intensity was expressed as a percentage of the mean of the control for each experiment. Mean \pm SEM is shown. For details, see supplemental Table 1 (available at www.jneurosci.org as supplemental material). $A-C$, Induction of BMP blockade in adult Tv cluster neurons (blue; anti-Eyes absent) for $10 \mathrm{~d}$ reduced FMRFa transcript (red) in Tv neurons (arrow). High nEGFP (green) expression showed GAL4 activity. D, Scatter plot shows that BMP blockade in $t k v^{D N}$; wit ${ }^{D N}$ flies (TW) and $M a d^{D N}$ flies (M) significantly reduced FMRFa expression in all Tv neurons, when compared with $w^{1118}$ control flies (w). Note that these data are included in Figure $4 \mathrm{H}$ for the $10 \mathrm{~d}$ time point. ${ }^{*} p<0.0001$ compared with $w^{1718}$ control. E-G, After $10 \mathrm{~d}$ of recovery from BMP blockade, FMRFa FISH (red) was fully restored to control levels. Note low-level nEGFP expression (green), indicative of nEGFP expression during the induction period. $\boldsymbol{H}$, Scatter plot shows that recovery from BMP blockade resulted in a complete restoration of FMRFa FISH levels, with no significant difference seen between $w^{1118}$ control flies (w), $t k v^{D N}$; wit ${ }^{D N}$ flies (TW), or Mad ${ }^{D N}$ flies (M).

In summary, these data show that adult $\mathrm{Tv}$ neurons retain the capacity to reestablish normal FMRFa expression after an acute $10 \mathrm{~d}$ block of BMP signaling that had dramatically reduced FM$\mathrm{RFa}$ transcript levels.

\section{Late-onset expression of mutant Glued in adult Tv neurons} blocked retrograde BMP signaling and downregulated FMRFa, in a reversible manner

The above data led us to the hypothesis that neurodegenerative disease pathologies may disrupt gene expression in adult neurons by disrupting retrograde transport of essential target-derived signals. We tested this hypothesis using mutant Glued (Glued ${ }^{D N}$ ) (Allen et al., 1999). Glued mutation has been linked to familial and sporadic amyotrophic lateral sclerosis (ALS) (Puls et al., 2003; Münch et al., 2004). Moreover, mutant Glued disrupts dynein motor function in Drosophila (Martin et al., 1999) and vertebrates (Levy et al., 2006) and recapitulates key features of ALS in mouse models (Chevalier-Larsen et al., 2008; Laird et al., 2008).

We generated flies to spatiotemporally target Glued ${ }^{\mathrm{DN}}$ expression (UAS-Glued ${ }^{D N}$ ) in adult Tv neurons using the TARGET system [genotype (FMRFa-lacZ),ap ${ }^{G A L 4} / U A S-$ Glued $^{D N}$; UAS- $\left.n E G F P, t u b>G A L 80^{T S} /+\right]$. We tested the effect of late-onset Glued ${ }^{\mathrm{DN}}$ expression on maintenance of FMRFa expression. We raised $w^{1118}$ control and Glued ${ }^{D N}$ flies at $18^{\circ} \mathrm{C}$ until A1. First, we subsequently maintained flies at $18^{\circ} \mathrm{C}$ for $10 \mathrm{~d}$ to control for genotype in the absence of GAL4 activity, which was verified by lack of nEGFP expression (Fig. $7 A, B$ ). After $10 \mathrm{~d}$ at $18^{\circ} \mathrm{C}$, the intensity of FISH for FMRFa transcript, normalized to the mean of $w^{1118}$ control, was not significantly different between $w^{1118}$ control (100 $\pm 12.4 ; n=15 \mathrm{Tv}$ neurons) and Glued $^{D N}$ flies (106.3 $\pm 14.2 \% ; n=20$; NSD) (Fig. 7C; supplemental Table 3, available at www.jneurosci.org as supplemental material). Second, we induced Glued ${ }^{D N}$ for $5 \mathrm{~d}$ at $29^{\circ} \mathrm{C}$; FMRFa expression in Glued $^{D N}$ flies fell to $28.8 \pm 4.9 \%\left(n=20 ; p=1.7 \times 10^{-13}\right)$, compared with that of $w^{1118}$ control flies $(100 \pm 4.7 \% ; n=34)$ (Fig. 7D-F; supplemental Table 3, available at www.jneurosci.org as supplemental material). Third, we tested whether Tv neurons were able to recover from that acute period of Glued $^{D N}$ induction that downregulated FMRFa expression. We raised $w^{1118}$ control and Glued ${ }^{D N}$ flies at $18^{\circ} \mathrm{C}$ until A1. They were then switched to $29^{\circ} \mathrm{C}$ for $5 \mathrm{~d}$ to induce GAL4 activity. Flies were then returned to $18^{\circ} \mathrm{C}$ for an additional $10 \mathrm{~d}$ of recovery. Remarkably, after the 10 d recovery period, FMRFa levels were restored to $194.6 \pm$ 

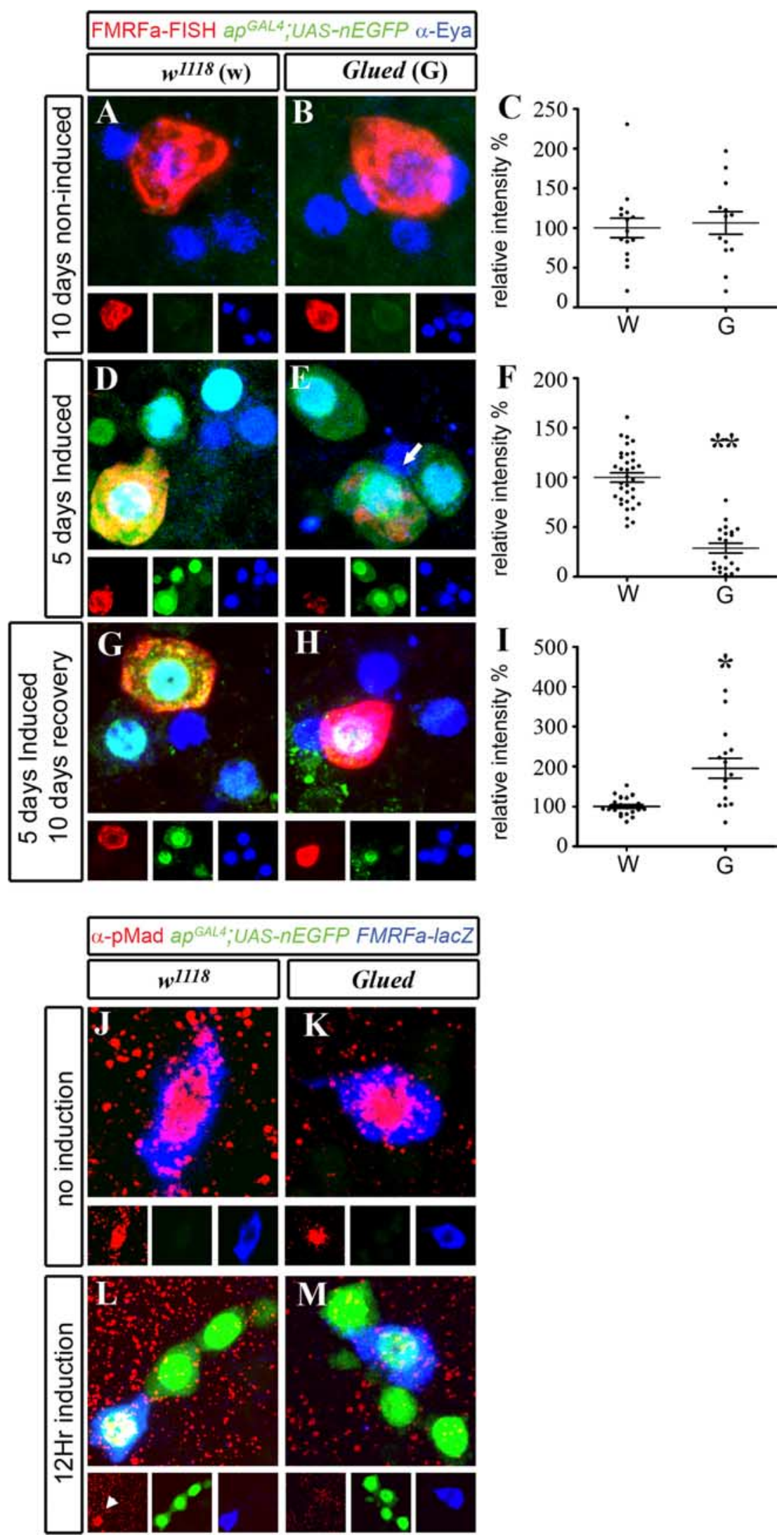

Figure 7. Late-onset expression of mutant Glued blocked retrograde BMP signaling and downregulated FMRFa, in a reversible manner. Genotypes were as follows: $w^{1718}$ control flies $(\boldsymbol{A}, \boldsymbol{D}, \boldsymbol{G})(a)^{G A L 4} /+$; tub-GAL80 ${ }^{T S}$,UAS-nEGFP/+); Glued ${ }^{D N}$ flies $(\boldsymbol{B}, \boldsymbol{E}, \boldsymbol{H})\left(a p^{G A L 4} / \mathrm{UAS}-\right.$ Glued $^{\Delta 84} ;$ tub-GAL80 $0^{T S}$, UAS-nEGFP/+). Flies were raised at $18^{\circ} \mathrm{C}$ until A1. They were then kept at $18^{\circ} \mathrm{C}$ for $10 \mathrm{~d}$ to block GAL 4 induction $(\boldsymbol{A}-\mathbf{C})$, switched to $29^{\circ} \mathrm{C}$ for $5 \mathrm{~d}$ to induce GAL4 activity $(\boldsymbol{D}-\boldsymbol{F})$, or switched to $29^{\circ} \mathrm{C}$ for $5 \mathrm{~d}(\mathbf{G}-\boldsymbol{I})$, and then returned to $18^{\circ} \mathrm{C}$ for $10 \mathrm{~d}$ to allow neurons to recover from Glued ${ }^{\mathrm{DN}}$ expression. $C, \boldsymbol{F}, \boldsymbol{I}$, Scatter plots show relative pixel intensity of FMRFa FISH in individual Tv neurons of $w^{1118}$ control (w), and Glued ${ }^{D N}$ flies (G). FMRFa FISH intensity was expressed as a percentage of the mean of the control for each
$24.9 \%(n=15 ; p=0.00011)$ of $w^{1118}$ control flies $(100 \pm 4.8 \%$; $n=21)$ (Fig. $7 G-I$; supplemental Table 3, available at www. jneurosci.org as supplemental material). In summary, overexpression of Glued ${ }^{\mathrm{DN}}$ in adult $\mathrm{Tv}$ neurons led to a profound downregulation of FMRFa expression.

We next examined whether BMP retrograde signaling is blocked by Glued ${ }^{\mathrm{DN}}$, by testing nuclear pMad accumulation in $\mathrm{Tv}$ neurons in $w^{1118}$ control and Glued ${ }^{D N}$ flies (Fig. 7J-M). We raised $w^{1118}$ control and Glued $^{D N}$ flies at $18^{\circ} \mathrm{C}$ until A1. First, we examined pMad immunoreactivity in $\mathrm{Tv}$ nuclei at $\mathrm{A} 1$, before induction at $29^{\circ} \mathrm{C}$. In both $w^{1118}$ control and Glued ${ }^{D N}$ flies, $100 \%$ of Tv neurons expressed FMRFalacZ and pMad immunoreactivity $(n=6$; $n=12$ Tv neurons, respectively). Next, we induced $a p^{G A L 4}$ activity by switching animals to $29^{\circ} \mathrm{C}$. After just $12 \mathrm{~h}$ of induction, we found that pMad nuclear accumulation was observed in $0 \%$ of Tv neurons in Glued $^{D N}$ flies ( $n=29$ Tv neurons), as opposed to $100 \%$ of Tv neurons in $w^{1118}$ controls $(n=15)$. This shows that acute

experiment. Mean \pm SEM is shown. For details, see supplemental Table 1 (available at www.jneurosci.org as supplemental material). $\boldsymbol{A}, \boldsymbol{B}$, Flies were kept at $18^{\circ} \mathrm{C}$ for $10 \mathrm{~d}$. Note the lack of nEGFP (green) in Tv cluster neurons (blue; antiEyes absent), showing lack of GAL4 activity. FMRFa FISH (red) was high in noninduced $w^{1118}$ control flies $(\boldsymbol{A})$ and Glued ${ }^{D N}$ flies $(\boldsymbol{B})$. C, Scatter plot shows that there was no significant difference in FMRFa transcript in individual Tv neurons between noninduced $w^{1118}$ control (w), and Glued ${ }^{D N}$ flies (G). D, $\boldsymbol{E}$, Five days of induced Glued ${ }^{D N}$ expression in adult Tv cluster neurons (blue; anti-Eyes absent) significantly reduced FMRFa FISH (red) in Tv neurons (arrow). High nEGFP (green) expression showed induction of GAL4 activity. $\boldsymbol{F}$, Scatter plot shows that FMRFa transcript was downregulated in all Tv neurons in Glued $^{D N}$ flies (G), compared with $w^{1118}$ control flies (w). ${ }^{* *} p<0.0001$ compared with control. $\mathbf{G}, \boldsymbol{H}$, After $10 \mathrm{~d}$ of recovery from Glued ${ }^{\mathrm{DN}}$ expression, FMRFa FISH (red) was restored to above control levels (194.6 $\pm 24.9 \%)$. Note low nEGFP expression (green), indicative of nEGFP expression during the induction period. $I$, Scatter plot shows that, after recovery from Glued ${ }^{\mathrm{DN}}$ expression, FMRFa transcript was fully restored to above control levels $(G)$, when compared with $w^{1118}$ control flies (w). ${ }^{*} p<0.001$ compared with control. $J-M$, Flies of genotype FMRFa-lacZ, ap ${ }^{G A L 4} / C y 0$; tubGAL80 ${ }^{T S}$, UAS-nEGFP were crossed to either control $w^{1718}$ flies $(\boldsymbol{J}, \boldsymbol{L})$ or UAS-Glued ${ }^{D N}$ flies $(\boldsymbol{K}, \boldsymbol{M})$ to generate progeny that were raised at $18^{\circ} \mathrm{C}$. $J, \boldsymbol{K}$, No induction, A1 flies maintained at $18^{\circ} \mathrm{C}$. Note lack of $\mathrm{nEGFP}$ expression in both genotypes. In $w^{1118}$ control flies $(\boldsymbol{J})$ and UAS-Glued ${ }^{D N}$ flies $(\boldsymbol{K})$, there was no difference in the expression of FMRFa-lacZ (blue; anti- $\beta$ Gal) or nuclear pMad (red; anti-pMad) in Tv neurons. $L, M$, After $12 \mathrm{~h}$ induction at $29^{\circ} \mathrm{C}$, nEGFP expression was activated (green) in both genotypes. $L$, In $w^{1118}$ control flies, FMRFalacZ and nuclear pMad (arrowhead) expression was maintained in Tv neurons. $M$, In UAS-Glued ${ }^{D N}$ flies, FMRFa-lacZ expression was maintained, but nuclear accumulation of $\mathrm{pMad}$ was entirely absent in Tv neurons. 
Glued $^{\text {DN }}$ expression in adult Tv neurons rapidly blocked persistent retrograde transport of the BMP signal in adult Tv neurons.

In summary, these data support the hypothesis that maintenance of FMRFa expression in adult Tv neurons requires persistent retrograde BMP signaling. Moreover, we provide the first direct evidence that neurodegenerative disease-related disruption of axonal transport leads to the downregulation of phenotypic markers, such as the neuropeptide FMRFa, that depend on persistent target-dependent signaling. These findings highlight a novel mechanism by which neurodegenerative diseases may disrupt normal neuronal function. Importantly, our data further demonstrate that the effect of Glued ${ }^{D N}$ is fully reversible, in that neurons can restore normal target-dependent FMRFa expression after recovery from mutant Glued expression.

\section{Discussion}

Previously, we demonstrated that target-dependent neuronal differentiation is conserved from invertebrates to vertebrates by showing that expression of FMRFa in developing Drosophila Tv neurons is induced by retrograde BMP signaling (Allan et al., 2003). FMRFa is a stably expressed phenotypic marker of Tv neurons expressed throughout Drosophila life (Schneider et al., 1993). Despite the growing number of identified target-induced genes in vertebrates and Drosophila, it is unclear whether maintenance of the expression of those genes requires persistent retrograde signaling, or switches to cell-autonomous maintenance. Here, we address this question for FMRFa in Tv neurons. By cell-autonomous blockade of either BMP signaling or retrograde axon transport in Tv neurons, selectively in adult flies, we show that persistent retrograde BMP signaling is absolutely required to maintain FMRFa expression. To our knowledge, this is the first explicit demonstration that a specific retrograde signaling pathway is required to induce and then to maintain the expression of a stably expressed phenotypic marker in neurons.

\section{TGF $\beta$ superfamily ligands are conserved regulators of circulating peptide hormone levels}

Tv neurons secrete FMRFa into the fly circulatory system, the hemolymph, which is akin to the secretion of peptide hormones from the mammalian pituitary and pancreas into the circulation. Intriguingly, persistent BMP signaling is required to maintain the expression of insulin in pancreatic $\beta$-islet cells (Goulley et al., 2007 ), and persistent activin signaling is required to maintain the expression of follicle-stimulating hormone subunit $\beta(\mathrm{FSH} \beta)$ in pituitary gonadotrophs (DePaolo et al., 1992a,b; Guo et al., 1998; Kumar et al., 2003). Together with our results showing that BMP signaling maintains neuropeptide expression in Drosophila neuroendocrine neurons, these findings demonstrate that TGF $\beta$ superfamily signaling is a conserved mechanism for maintenance of circulatory peptide hormone levels in adults.

Circulating peptide hormones in vertebrates are typically under homeostatic regulation. Does BMP signaling participate in the homeostatic regulation of FMRFa in Drosophila? A precedent for homeostatic peptide hormone regulation by TGF $\beta$-type signaling comes from the well characterized regulation of $\mathrm{FSH} \beta$ during the estrous cycle by activin. The level of FSH $\beta$ transcription depends on the level of activin receptor signaling in pituitary gonadotrophs, which in turn is modulated by the balance of locally produced activin and circulating levels of inhibin, an activin antagonist secreted from the gonads (Gregory and Kaiser, 2004; Bilezikjian et al., 2006). In Drosophila, the level of BMP ligand or antagonist accessible to Tv neurons may be responsive to an unknown cue that reads through to physiologically instructive levels of FMRFa. We have not detected any periodicity in FMRFa expression, which would be suggestive of homeostatic modulation, but neither have we ruled out such a possibility. BMP signaling has a well documented role in neuromuscular efficacy in Drosophila larvae (McCabe et al., 2003; Keshishian and Kim, 2004), and pharmacological administration of FMRFa enhances neuron-evoked contractility of larval Drosophila body wall muscles (Hewes et al., 1998; Clark et al., 2008). These findings have led to the untested proposal that activity-dependent BMP signaling feeds back to FMRFa transcription to influence neuromuscular efficacy (Keshishian and Kim, 2004). However, there is no evidence to rule out a simpler alternative hypothesis that retrograde BMP signaling may simply function to maintain high level FMRFa transcription independent of any homeostatic regulatory role. Future studies will need to discriminate between these models and define the role(s) of FMRFa in adult flies.

\section{Retrograde maintenance of neuronal phenotype in adults}

After neurons differentiate, they must maintain their differentiated state for the lifetime of the animal. Blau and Baltimore (1991) postulated that the differentiated state of a cell requires persistent active regulation, rather than lapsing into a passive "locked-in" state. Evidence has emerged from work in Caenorhabditis elegans to show that core "terminal selector" transcription factors, which differentiate neuronal phenotype during development, are subsequently required to maintain that identity after development. Notably, the expression of these transcription factors is maintained in an autoregulatory manner, providing an intrinsic, cell-autonomous mechanism for maintenance of neuronal phenotype (Hobert, 2008; Etchberger et al., 2009). Maintenance of extrinsically induced gene expression poses a distinct problem for maintenance. In neuronal progenitor cells, genes that are induced by inductive extrinsic signals subsequently switch to an intrinsic mechanism for maintenance (Edlund and Jessell, 1999). In contrast, our data now show that maintenance of extrinsically activated genes in postmitotic Drosophila neurons requires persistent extrinsic signaling, rather than switching to intrinsic, cell-autonomous regulation. This is the first demonstration that persistent TGF $\beta$-type signaling is required to maintain neuronal phenotype, and highlights the possibility that many of the identified target-induced genes in the vertebrate nervous system may likewise require persistent retrograde signaling for their maintenance.

Work in vertebrates has provided compelling evidence that neurotrophins act retrogradely to maintain adult neuronal phenotype. Axotomy of adult sympathetic and sensory neurons alters their expression of specific neurotransmitters and neuropeptides (Zigmond et al., 1998). As nerve growth factor (NGF) is expressed at the targets of those neurons, it is notable that NGF administration partially blocks axotomy-induced phenotypic changes (Verge et al., 1995) and that NGF function-blocking antibodies partially recapitulate axotomy-induced changes in intact neurons (Shadiack et al., 2001). Similarly, cholinergic markers are downregulated in murine CBF (cholinergic basal forebrain) neurons in transgenic mice that express an anti-NGF antibody or after target tissue ablation (Sofroniew et al., 1993; Capsoni et al., 2000).

Such vertebrate studies indicate that retrograde signaling maintains neuronal phenotype, but in most cases it has been difficult to discriminate between (1) loss of gene expression as a direct consequence of loss of a specific retrograde signal and (2) loss of gene expression as an indirect consequence of neuronal injury, degeneration, or regeneration. The use of conditional 
mouse knock-outs and transgenics will circumvent many of these issues and promises a wealth of insight. For example, conditional BDNF knock-outs have uncovered a role for anterograde BDNF signaling in the maintenance of serotonin receptor expression in the adult prefrontal cortex (Rios et al., 2006). In our study, we have circumvented these issues using the TARGET spatiotemporal transgene targeting system (McGuire et al., 2004), which provides several advantages: (1) Using reversible temperaturedependent transgene expression, we were able to block retrograde BMP signaling cell-autonomously at any time point in intact Tv neurons in freely moving flies. (2) We were able to examine FMRFa expression in the same individually identifiable neurons between experimental groups. (3) The use of cellspecific markers that are not BMP-dependent, apterous and eyes absent, allowed us to identify Tv neurons in the absence of FM$\mathrm{RFa}$ expression, confirming that Tv neurons do not require retrograde BMP signaling for survival. Using this methodology, our results provide direct evidence to strengthen the conclusions from vertebrate work indicating a role for retrograde signaling in the maintenance of neuronal phenotype.

\section{Inhibition of persistent retrograde signaling: a mechanism for disrupting neuronal phenotype in neurodegenerative disease} This study has demonstrated a requirement for persistent retrograde signaling in the maintenance of a gene critical to subsetspecific neuronal phenotype and function. These data are of particular significance in light of the many neurodegenerative disorders, such as ALS, Alzheimer's disease, and Huntington's disease, that have been increasingly attributed to defects in axon transport (Gunawardena and Goldstein, 2004; Chevalier-Larsen and Holzbaur, 2006; De Vos et al., 2008). To block retrograde transport, we overexpressed a dominantly acting Glued mutant in Tv axons. Importantly, dominantly acting Glued mutations have been linked to ALS (Puls et al., 2003; Münch et al., 2004) and mouse models recapitulate many cellular and functional deficits of ALS (Levy et al., 2006; Chevalier-Larsen et al., 2008; Laird et al., 2008). Glued is a critical component of the dynactin complex necessary for dynein motor function in retrograde axon transport (Chevalier-Larsen and Holzbaur, 2006; De Vos et al., 2008), and together with data showing similar phenotypes have been described in mouse dynein mutants or on dynamitin overexpression (LaMonte et al., 2002; Hafezparast et al., 2003; Laird et al., 2008), numerous lines of evidence converge to indicate that axonal transport defects may be causative for ALS.

It is still unclear how reduced axon transport leads to neuronal dysfunction and degeneration. A widely held hypothesis proposes that disrupted axon transport diminishes target-derived neurotrophin signaling (Salehi et al., 2003; Blesch, 2006), depriving neurons of necessary trophic support and leading to degeneration. Evidence for this link has come from elegant work using mice trisomic for amyloid precursor protein (APP) to model early-onset Alzheimer's disease in Down's syndrome. This showed that APP overexpression inhibited retrograde NGF transport, leading to presynaptic neuron atrophy and reduced expression of the p75 low-affinity NGF receptor (Cooper et al., 2001; Salehi et al., 2006).

Our data show that blockade of dynein-mediated axonal transport eliminates retrograde BMP signaling in adult neurons. We further show that this directly impacts neuronal phenotype by eliminating the expression of a stably expressed, targetdependent gene that defines the identity and function of the neuron. Importantly, this occurs in the absence of overt neuronal degeneration. Thus, we postulate that the maintenance of neuro- nal phenotype may be particularly vulnerable to pathologies that diminish retrograde signaling, even in the absence of overt neuronal degeneration or death. Importantly, both our work and that of others suggest that the loss of neuronal phenotype resulting from disrupted axonal transport may be reversible. Cooper et al. (2001) found that reduced retrograde NGF transport in cholinergic basal forebrain neurons led to neuronal atrophy and reduced p75 expression, but that both could subsequently be fully reversed by NGF infusion. Similarly, our recovery data show that FMRFa expression was fully restored after retrograde BMP signaling was reestablished. Both studies strongly suggest that loss of neuronal phenotype in neurodegenerative disease may be treatable.

\section{References}

Ai X, Cappuzzello J, Hall AK (1999) Activin and bone morphogenetic proteins induce calcitonin gene-related peptide in embryonic sensory neurons in vitro. Mol Cell Neurosci 14:506-518.

Allan DW, St Pierre SE, Miguel-Aliaga I, Thor S (2003) Specification of neuropeptide cell identity by the integration of retrograde BMP signaling and a combinatorial transcription factor code. Cell 113:73-86.

Allan DW, Park D, St Pierre SE, Taghert PH, Thor S (2005) Regulators acting in combinatorial codes also act independently in single differentiating neurons. Neuron 45:689-700.

Allen MJ, Shan X, Caruccio P, Froggett SJ, Moffat KG, Murphey RK (1999) Targeted expression of truncated glued disrupts giant fiber synapse formation in Drosophila. J Neurosci 19:9374-9384.

Benveniste RJ, Thor S, Thomas JB, Taghert PH (1998) Cell type-specific regulation of the Drosophila FMRF-NH2 neuropeptide gene by Apterous, a LIM homeodomain transcription factor. Development 125:4757-4765.

Bilezikjian LM, Blount AL, Donaldson CJ, Vale WW (2006) Pituitary actions of ligands of the TGF-beta family: activins and inhibins. Reproduction 132:207-215.

Blau HM, Baltimore D (1991) Differentiation requires continuous regulation. J Cell Biol 112:781-783.

Blesch A (2006) Neurotrophic factors in neurodegeneration. Brain Pathol 16:295-303.

Brown HL, Cherbas L, Cherbas P, Truman JW (2006) Use of time-lapse imaging and dominant negative receptors to dissect the steroid receptor control of neuronal remodeling in Drosophila. Development 133:275-285.

Bucelli RC, Gonsiorek EA, Kim WY, Bruun D, Rabin RA, Higgins D, Lein PJ (2008) Statins decrease expression of the proinflammatory neuropeptides calcitonin gene-related peptide and substance $\mathrm{P}$ in sensory neurons. J Pharmacol Exp Ther 324:1172-1180.

Capsoni S, Ugolini G, Comparini A, Ruberti F, Berardi N, Cattaneo A (2000) Alzheimer-like neurodegeneration in aged antinerve growth factor transgenic mice. Proc Natl Acad Sci U S A 97:6826-6831.

Chevalier-Larsen E, Holzbaur EL (2006) Axonal transport and neurodegenerative disease. Biochim Biophys Acta 1762:1094-1108.

Chevalier-Larsen ES, Wallace KE, Pennise CR, Holzbaur EL (2008) Lysosomal proliferation and distal degeneration in motor neurons expressing the G59S mutation in the p150Glued subunit of dynactin. Hum Mol Genet 17:1946-1955.

Clark J, Milakovic M, Cull A, Klose MK, Mercier AJ (2008) Evidence for postsynaptic modulation of muscle contraction by a Drosophila neuropeptide. Peptides 29:1140-1149.

Cooper JD, Salehi A, Delcroix JD, Howe CL, Belichenko PV, Chua-Couzens J, Kilbridge JF, Carlson EJ, Epstein CJ, Mobley WC (2001) Failed retrograde transport of NGF in a mouse model of Down's syndrome: reversal of cholinergic neurodegenerative phenotypes following NGF infusion. Proc Natl Acad Sci U S A 98:10439-10444.

Coulombe JN, Kos K (1997) Target tissue influence on somatostatin expression in the avian ciliary ganglion. Ann N Y Acad Sci 814:209-225.

Darland DC, Nishi R (1998) Activin A and follistatin influence expression of somatostatin in the ciliary ganglion in vivo. Dev Biol 202:293-303.

DePaolo LV, Shimonaka M, Ling N (1992a) Regulation of pulsatile gonadotropin secretion by estrogen, inhibin, and follistatin (activin-binding protein) in ovariectomized rats. Biol Reprod 46:898-904.

DePaolo LV, Bald LN, Fendly BM (1992b) Passive immunoneutralization 
with a monoclonal antibody reveals a role for endogenous activin-B in mediating FSH hypersecretion during estrus and following ovariectomy of hypophysectomized, pituitary-grafted rats. Endocrinology 130:1741-1743.

De Vos KJ, Grierson AJ, Ackerley S, Miller CC (2008) Role of axonal transport in neurodegenerative diseases. Annu Rev Neurosci 31:151-173.

Duong CV, Geissen M, Rohrer H (2002) The developmental expression of vasoactive intestinal peptide (VIP) in cholinergic sympathetic neurons depends on cytokines signaling through LIFRbeta-containing receptors. Development 129:1387-1396.

Edlund T, Jessell TM (1999) Progression from extrinsic to intrinsic signaling in cell fate specification: a view from the nervous system. Cell 96:211-224

Ernsberger U, Rohrer H (1999) Development of the cholinergic neurotransmitter phenotype in postganglionic sympathetic neurons. Cell Tissue Res 297:339-361.

Etchberger JF, Flowers EB, Poole RJ, Bashllari E, Hobert O (2009) Cisregulatory mechanisms of left/right asymmetric neuron-subtype specification in C. elegans. Development 136:147-160.

Goulley J, Dahl U, Baeza N, Mishina Y, Edlund H (2007) BMP4-BMPR1A signaling in beta cells is required for and augments glucose-stimulated insulin secretion. Cell Metab 5:207-219.

Gregory SJ, Kaiser UB (2004) Regulation of gonadotropins by inhibin and activin. Semin Reprod Med 22:253-267.

Gunawardena S, Goldstein LS (2004) Cargo-carrying motor vehicles on the neuronal highway: transport pathways and neurodegenerative disease. J Neurobiol 58:258-271.

Guo Q, Kumar TR, Woodruff T, Hadsell LA, DeMayo FJ, Matzuk MM (1998) Overexpression of mouse follistatin causes reproductive defects in transgenic mice. Mol Endocrinol 12:96-106.

Haerry TE, Khalsa O, O'Connor MB, Wharton KA (1998) Synergistic signaling by two BMP ligands through the SAX and TKV receptors controls wing growth and patterning in Drosophila. Development 125:3977-3987.

Hafezparast M, Klocke R, Ruhrberg C, Marquardt A, Ahmad-Annuar A, Bowen S, Lalli G, Witherden AS, Hummerich H, Nicholson S, Morgan PJ, Oozageer R, Priestley JV, Averill S, King VR, Ball S, Peters J, Toda T, Yamamoto A, Hiraoka Y, et al. (2003) Mutations in dynein link motor neuron degeneration to defects in retrograde transport. Science 300:808-812.

Hewes RS, Snowdeal EC 3rd, Saitoe M, Taghert PH (1998) Functional redundancy of FMRFamide-related peptides at the Drosophila larval neuromuscular junction. J Neurosci 18:7138-7151.

Hippenmeyer S, Kramer I, Arber S (2004) Control of neuronal phenotype: what targets tell the cell bodies. Trends Neurosci 27:482-488.

Hobert O (2008) Regulatory logic of neuronal diversity: terminal selector genes and selector motifs. Proc Natl Acad Sci U S A 105:20067-20071.

Hodge LK, Klassen MP, Han BX, Yiu G, Hurrell J, Howell A, Rousseau G, Lemaigre F, Tessier-Lavigne M, Wang F (2007) Retrograde BMP signaling regulates trigeminal sensory neuron identities and the formation of precise face maps. Neuron 55:572-586.

Keshishian H, Kim YS (2004) Orchestrating development and function: retrograde BMP signaling in the Drosophila nervous system. Trends Neurosci 27:143-147.

Kumar TR, Agno J, Janovick JA, Conn PM, Matzuk MM (2003) Regulation of FSHbeta and GnRH receptor gene expression in activin receptor II knockout male mice. Mol Cell Endocrinol 212:19-27.

Laird FM, Farah MH, Ackerley S, Hoke A, Maragakis N, Rothstein JD, Griffin J, Price DL, Martin LJ, Wong PC (2008) Motor neuron disease occurring in a mutant dynactin mouse model is characterized by defects in vesicular trafficking. J Neurosci 28:1997-2005.

LaMonte BH, Wallace KE, Holloway BA, Shelly SS, Ascaño J, Tokito M, Van Winkle T, Howland DS, Holzbaur EL (2002) Disruption of dynein/dynactin inhibits axonal transport in motor neurons causing late-onset progressive degeneration. Neuron 34:715-727.

Levy JR, Sumner CJ, Caviston JP, Tokito MK, Ranganathan S, Ligon LA, Wallace KE, LaMonte BH, Harmison GG, Puls I, Fischbeck KH, Holzbaur EL (2006) A motor neuron disease-associated mutation in p150Glued perturbs dynactin function and induces protein aggregation. J Cell Biol 172:733-745.

Lundquist T, Nässel DR (1990) Substance P-, FMRFamide-, and gastrin/ cholecystokinin-like immunoreactive neurons in the thoraco-abdominal ganglia of the flies Drosophila and Calliphora. J Comp Neurol 294:161-178.

Marqués G, Haerry TE, Crotty ML, Xue M, Zhang B, O’Connor MB (2003) Retrograde Gbb signaling through the Bmp type 2 receptor wishful thinking regulates systemic FMRFa expression in Drosophila. Development 130:5457-5470.

Martin M, Iyadurai SJ, Gassman A, Gindhart JG Jr, Hays TS, Saxton WM (1999) Cytoplasmic dynein, the dynactin complex, and kinesin are interdependent and essential for fast axonal transport. Mol Biol Cell 10:3717-3728.

Martin-Caraballo M, Dryer SE (2002) Glial cell line-derived neurotrophic factor and target-dependent regulation of large-conductance KCa channels in developing chick lumbar motoneurons. J Neurosci 22:10201-10208.

McCabe BD, Marqués G, Haghighi AP, Fetter RD, Crotty ML, Haerry TE, Goodman CS, O'Connor MB (2003) The BMP homolog Gbb provides a retrograde signal that regulates synaptic growth at the Drosophila neuromuscular junction. Neuron 39:241-254.

McGuire SE, Le PT, Osborn AJ, Matsumoto K, Davis RL (2003) Spatiotemporal rescue of memory dysfunction in Drosophila. Science 302:1765-1768.

McGuire SE, Mao Z, Davis RL (2004) Spatiotemporal gene expression targeting with the TARGET and gene-switch systems in Drosophila. Sci STKE 2004:pl6.

Miguel-Aliaga I, Allan DW, Thor S (2004) Independent roles of the dachshund and eyes absent genes in BMP signaling, axon pathfinding and neuronal specification. Development 131:5837-5848.

Miguel-Aliaga I, Thor S, Gould AP (2008) Postmitotic specification of Drosophila insulinergic neurons from pioneer neurons. PLoS Biol 6:e58.

Münch C, Sedlmeier R, Meyer T, Homberg V, Sperfeld AD, Kurt A, Prudlo J, Peraus G, Hanemann CO, Stumm G, Ludolph AC (2004) Point mutations of the p150 subunit of dynactin (DCTN1) gene in ALS. Neurology 63:724-726.

Nishi R (2003) Target-mediated control of neural differentiation. Prog Neurobiol 69:213-227.

O'Brien MA, Schneider LE, Taghert PH (1991) In situ hybridization analysis of the FMRFamide neuropeptide gene in Drosophila. II. Constancy in the cellular pattern of expression during metamorphosis. J Comp Neurol 304:623-638.

Patel TD, Jackman A, Rice FL, Kucera J, Snider WD (2000) Development of sensory neurons in the absence of NGF/TrkA signaling in vivo. Neuron 25:345-357.

Pavelock KA, Girard BM, Schutz KC, Braas KM, May V (2007) Bone morphogenetic protein down-regulation of neuronal pituitary adenylate cyclase-activating polypeptide and reciprocal effects on vasoactive intestinal peptide expression. J Neurochem 100:603-616.

Predel R, Wegener C, Russell WK, Tichy SE, Russell DH, Nachman RJ (2004) Peptidomics of CNS-associated neurohemal systems of adult Drosophila melanogaster: a mass spectrometric survey of peptides from individual flies. J Comp Neurol 474:379-392.

Puls I, Jonnakuty C, LaMonte BH, Holzbaur EL, Tokito M, Mann E, Floeter MK, Bidus K, Drayna D, Oh SJ, Brown RH Jr, Ludlow CL, Fischbeck KH (2003) Mutant dynactin in motor neuron disease. Nat Genet 33:455-456.

Rao S, Lang C, Levitan ES, Deitcher DL (2001) Visualization of neuropeptide expression, transport, and exocytosis in Drosophila melanogaster. J Neurobiol 49:159-172.

Rios M, Lambe EK, Liu R, Teillon S, Liu J, Akbarian S, Roffler-Tarlov S, Jaenisch R, Aghajanian GK (2006) Severe deficits in 5-HT2A-mediated neurotransmission in BDNF conditional mutant mice. J Neurobiol 66:408-420.

Salehi A, Delcroix JD, Mobley WC (2003) Traffic at the intersection of neurotrophic factor signaling and neurodegeneration. Trends Neurosci 26:73-80.

Salehi A, Delcroix JD, Belichenko PV, Zhan K, Wu C, Valletta JS, TakimotoKimura R, Kleschevnikov AM, Sambamurti K, Chung PP, Xia W, Villar A, Campbell WA, Kulnane LS, Nixon RA, Lamb BT, Epstein CJ, Stokin GB, Goldstein LS, Mobley WC (2006) Increased App expression in a mouse model of Down's syndrome disrupts NGF transport and causes cholinergic neuron degeneration. Neuron 51:29-42.

Schneider LE, O’Brien MA, Taghert PH (1991) In situ hybridization analy- 
sis of the FMRFamide neuropeptide gene in Drosophila. I. Restricted expression in embryonic and larval stages. J Comp Neurol 304:608-622.

Schneider LE, Sun ET, Garland DJ, Taghert PH (1993) An immunocytochemical study of the FMRFamide neuropeptide gene products in Drosophila. J Comp Neurol 337:446-460.

Shadiack AM, Sun Y, Zigmond RE (2001) Nerve growth factor antiserum induces axotomy-like changes in neuropeptide expression in intact sympathetic and sensory neurons. J Neurosci 21:363-371.

Shoji-Kasai Y, Ageta H, Hasegawa Y, Tsuchida K, Sugino H, Inokuchi K (2007) Activin increases the number of synaptic contacts and the length of dendritic spine necks by modulating spinal actin dynamics. J Cell Sci 120:3830-3837.

Sofroniew MV, Cooper JD, Svendsen CN, Crossman P, Ip NY, Lindsay RM, Zafra F, Lindholm D (1993) Atrophy but not death of adult septal cholinergic neurons after ablation of target capacity to produce mRNAs for NGF, BDNF, and NT3. J Neurosci 13:5263-5276.

Stanke M, Duong CV, Pape M, Geissen M, Burbach G, Deller T, Gascan H, Otto C, Parlato R, Schütz G, Rohrer H (2006) Target-dependent specification of the neurotransmitter phenotype: cholinergic differentiation of sympathetic neurons is mediated in vivo by gp 130 signaling. Development 133:141-150.

Sun M, Thomas MJ, Herder R, Bofenkamp ML, Selleck SB, O'Connor MB
(2007) Presynaptic contributions of chordin to hippocampal plasticity and spatial learning. J Neurosci 27:7740-7750.

Takaesu NT, Herbig E, Zhitomersky D, O'Connor MB, Newfeld SJ (2005) DNA-binding domain mutations in SMAD genes yield dominantnegative proteins or a neomorphic protein that can activate WG target genes in Drosophila. Development 132:4883-4894.

Verge VM, Richardson PM, Wiesenfeld-Hallin Z, Hökfelt T (1995) Differential influence of nerve growth factor on neuropeptide expression in vivo: a novel role in peptide suppression in adult sensory neurons. J Neurosci 15:2081-2096.

Wegener C, Reinl T, Jänsch L, Predel R (2006) Direct mass spectrometric peptide profiling and fragmentation of larval peptide hormone release sites in Drosophila melanogaster reveals tagma-specific peptide expression and differential processing. J Neurochem 96:1362-1374.

Xu P, Hall AK (2006) The role of activin in neuropeptide induction and pain sensation. Dev Biol 299:303-309.

Xu P, Van Slambrouck C, Berti-Mattera L, Hall AK (2005) Activin induces tactile allodynia and increases calcitonin gene-related peptide after peripheral inflammation. J Neurosci 25:9227-9235.

Zigmond R, Mohney R, Schreiber R, Shadiack A, Sun Y, Vaccariello YS, Zhou $Y$ (1998) Changes in gene expression in adult sympathetic neurons after axonal injury. Adv Pharmacol 42:899-903. 